\title{
DOĞU TRAKYA BULUNTUSU SAVUNMA VE SALDIRI GEREÇLERI
}

\author{
Archaeological Defense and Attack Equipment Finds in Eastern Thrace
}

Ergün KARACA*

ÖZ: İnsanoğlunun, başta av, savaş ve statü göstergesi olarak kullandığı savaş gereçleri kültürel ve dönemsel farklılıklar göstermektedir. Ancak savaş gereçleri, savunma ve saldırı gereci şeklinde iki temel gruba ayrılır. Düşmanı saf dışı bırakmak için saldırı, kendisini koruması için de savunma gereçleri kullanılmış ve bunlar sürekli geliştirilmiştir. Doğu Trakya'da kazı ve yüzey araştırması çalışmalarının az olmasına karşın gerek saldırı, gerekse savunma amaçlı çeşitli gereçler tespit edilmiştir. Bölgede bulunan savaş gereçlerine baktığımızda özellikle en çok tümülüslere mezar hediyesi şeklinde bırakıldığ 1 görülmektedir. Bunun yanı sıra yerleşim yerleri ve tekil buluntu şeklinde bölge müzelerine geldikleri görülür. Savaş gereçleri zırh, miğfer, kalkan gibi savunma gereçleri ile kılıç, mızrak ucu, ok ucu ve sapan tanesi gibi saldırı gereçlerinden oluşur. Bölgede en çok bulunanların başında ok ve mızrak uçları gelmektedir. Bunları zırh ve kalkanlar izler. En erken buluntular Kozman Deresi'nde bulunduğu belirtilen kılıçlar ve mızrak uçlarıdır. Bununla birlikte, buluntuların özellikle üç tarih aralığında yoğunlaştığı görülür. İlk grup MÖ 6. yüzyıl; ikinci grup MÖ 4. yüzyıl; üçüncü grup ise MS 1.-2. yüzyıl arasıdır. Bu üç döneminin yoğunlaştı̆̆ zaman dilimlerine bakacak olursak, ilki Pers hâkimiyeti, ikincisi Makedon hâkimiyeti, üçüncüsü ise Roma İmparatorluğu hâkimiyetinin olduğu döneme denk gelmektedir.

Anahtar Kelimeler: Trakya, Asker, silah, Tümülüs, Bronz, Demir

ABSTRACT: War tools and equipment used by human beings as hunting, war and status indicators show cultural and periodic differences. However, combat vehicles are divided into two basic groups as defensive and offensive vehicles. Attack tools were used to eliminate the enemy and defensive tools were used to protect themselves, and they were constantly tried to improve. Despite the scarcity of excavations and surveys in Eastern Thrace, various tools for both attack and defense have been identified. It is seen that they were mostly left as grave gifts to the Tumuli, as well as settlements and singular finds. When we look at the war vehicles in Eastern Thrace, they consist of defense tools such as armor, helmet, shield and attack tools such as swords, spearheads, arrowheads and slingshots. One of the most common uses from the region is the arrow and spear tip. The most common tools are armor and shield. Although the earliest finds are Kozman Deresi clouds, historically it is seen that the finds are * Dr., Trakya Üniversitesi, Edebiyat Fakültesi, Arkeoloji Bölümü, Edirne,
ergunkaraca@trakya.edu.tr, ORCID: 0000-0002-0270-3258

Geliș Tarihi / Received: 10.11.2021

Kabul Tarihi / Accepted: 02.12.2021

Yayın Tarihi / Published: 27.01.2022 
concentrated especially in two date ranges. The first group is from the 4th century BC, and the second group is from the 1 st-2nd century AD. century between. If we look at the time periods in which these two time periods are concentrated, the first corresponds to the period of Macedonian and the second Roman imperial domination.

Keywords: Thrace, Soldier, weapon, Tumulus, Bronze, Iron

\section{Giriş}

Antik Çağ savaş gereçleri iki ana gruba ayrılır. Bu grubun ilki savaşçıyı saldırıdan koruyan, onun yaralanmasını ve ölmesini önleyen "Savunma Gereçleri"dir. İkinci grubu ise karşısındakini çatışma ortamında saf dışı bırakmaya yarayan ve öldürücü boyutta darbe indiren "Saldırı Gereçleri" oluşturur.

Doğu Trakya olarak adlandırılan bölgede kazılardan elde edilen buluntular ile hibe ve zor alım şeklinde bölge müzelerine gelmiş birçok savaş gereci bulunmaktadır. Bunların bir kısmı kitap, makale ve tez gibi bilimsel çalışmalarda diğer buluntular içerisinde değerlendirilmiştir. Ancak sadece savunma ve saldırı gereçlerini ele alan bir çalışma bugüne dek yapılmamıştır. $\mathrm{Bu}$ makalenin amacı pek çoğu yayınlardan elde edilmek üzere, bölge müzelerinde yapılan araştırmalarla tespit edilmiş gereçleri de ekleyerek alana katkı sağlamaktır. ${ }^{1}$

\section{Savunma Gereçleri}

Bir savaşta ilk amaç rakibi öldürmek ya da yaralayarak onu saf dış1 bırakmaktır. Ancak rakibi yaralayarak saf dışı bırakmak kimi zaman öldürmekten daha iyidir. Bu yolla, ona yardım edecek olan birden fazla kişiyi de savaş dışı bırakmak mümkün olur. Ayrıca bu durum düşman safındakileri psikolojik açıdan yıkıma da sürükleyebilir. $\mathrm{Bu}$ nedenle savaşçıyı saldırıdan koruyacak ve onun hayatta kalmasını sağlayacak savunma gereçleri oldukça önemlidir.

Doğu Trakya'da bulunan savunma gereçlerinin zırh, miğfer ve kalkanlardan oluştuğu görülür. Bu buluntular Yündolan C, Naip, Eriklice, Vize A, Tekhöyük ve Vakıfiğdemir'de bulunmuştur (Resim 1). Bunlar içeresinde Vakıfiğdemir hariç olmak üzere tamamı tümülüs kazılarından gelmiştir.

\footnotetext{
${ }^{1}$ Makalede, MÖ 13. yüzyıl ile MS 4. yüzyıl arasındaki zaman dilimini kapsayan buluntular incelenmiştir. Buradaki amaç kabaca Tunç Çağı'nın sonundan Roma İmparatorluğu'nun ikiye bölünmesini içine alan zamana kadar ki savunma ve saldırı gereçleri incelemektedir.
} 
DOĞU TRAKYA BULUNTUSU

SAVUNMA VE SALDIRI GEREÇLERİ

\section{Zirh}

Savaşçı1 koruyan savunma gereçlerinin başında gelen zırh örneklerine baktığımızda Doğu Trakya'da Yündolan C, Naip ve Vize A tümülüslerinde bulunmuştur.

Yündolan C Tümülüsü'nde ${ }^{2}$ dikdörtgen demir levhaların ${ }^{3}$ deriden yapılmış iplerle birbirine tutturulması ile oluşturulmuş bir zırh tespit edilmiştir (Delemen vd. 2010a: 96; Delemen vd. 2010b: 6) (Resim 2.1). Z1rh diğer buluntularla birlikte değerlendirildiğinde MÖ 4. yüzyıl ortasına tarihlendirilmiştir (Delemen vd. 2010a: 96; Delemen vd. 2010b: 9-10).

Naip Tümülüsü'nde ${ }^{4}$ sekiz adet, ortası delik yuvarlak altın levha, yedi adet altın halka tespit edilmiştir ${ }^{5}$ (Resim 2.2). İnci Delemen, bu altın yuvarlak levha ile altın halkaların deriden şeritler yardımıyla demir zırh üzerinde kullanıldığını ve MÖ 4 . yüzyılın sonuna ${ }^{6}$ ait olduğu belirtilmiştir (Delemen, 2004: 107).

Vize A Tümülüsü ${ }^{7}$, mezar odası içinde yer alan lahit içerisinde, katlanarak bırakılmış, MS 1. yüzyıla tarihlendirilen Lorica squamata tipi $\mathrm{zurh}^{8}$ tespit edilmiştir (Mansel, 1940: 103-104; Onurkan, 1978: 47, 52; Aksan, 2015: 306-308) (Resim 2.3, 4). Bu zırhın en dışında bronz halkalar ${ }^{9}$ ile onlara geçirilmiş ağırlıklı şekilde bronz, bezeme oluşturmak için kullanılmış demir ve gümüş plakalar ${ }^{10}$ ve son olarak bunların içine

${ }^{2}$ Yündolan C Tümülüsü, Kırklareli, Yündalan Köyü'nün yaklaşık 2.7 km kadar kuzeyinde Koçasa mevkiinde yer alır. Kırklareli Müzesi Müdürlüğü tarafindan kaçak kazıdan dolayı 1999 yılında kurtarma kazısı gerçekleştirilmiştir.

${ }^{3}$ Dikdörtgen levhalar yaklaşık 1,3 cm genişliğindedir (Delemen vd. 2010a: 96).

${ }^{4}$ Naip Tümülüsü, Tekirdağ, Süleymanpaşa'ya bağlı Naip Köyü'nün yaklaşık 900 m kadar kuzeybatısında, Kızkulesi Mevkii adı ile bilinen sırtın kuzeydoğu ucunda yer alır. Kaçak kazılar nedeniyle 1984 ile1985 tarihleri arasında Tekirdağ Arkeoloji Müzesi tarafından tümülüste kurtarma kazısı yapılmıştır.

${ }^{5}$ Yuvarlak levhaların çapları 2,5 ile 3,1 cm, halkaların çapları ise 1,5 cm ile 1,8 cm arasında değişmektedir. Sekiz altın yuvak levha 1926-133, yedi altın halka ise 119-1925 numarasıyla Tekirdağ Arkeoloji Müzesi'ne kayıtlıdır (Delemen, 2004: 105).

${ }^{6}$ İnci Delemen, halkaların Geç Klasik-Hellenistik tarzda olduğunu belirtmiştir. Tümülüs ve buluntuların tarihi için bk. Delemen 2004: 113.

${ }^{7}$ Vize A Tümülüsü, Kırklareli, Vize İlçe merkezinin yaklaşık 3 km kadar güneyinde, ovada yer alan tümülüslerden biridir. Arif Müfid Mansel tarafından 1938 yılında kazı gerçekleştirilmiş ve çıkan buluntular İstanbul Arkeoloji Müzesi'ne taşınmıştır.

8 İstanbul Arkeoloji Müzeleri'nde 5731 envanter numarasıyla korunan zırh yaklaşık $65 \mathrm{~cm}$ uzunluğunda ve $55 \mathrm{~cm}$ genişliğindedir (Onurkan, 1988: 98; Aksan, 2015: 306).

${ }^{9}$ Bronz halkalar yaklaşık 0,3-0,4 cm çapındadır (Onurkan, 1988: 98; Aksan, 2015: 307).

${ }^{10}$ Plakalar 0,6 cm genişliğinde ve 1,2 cm uzunluğundadır (Onurkan, 1988: 99; Aksan, 2015: 307). 
yerleştirilmiş bej renginde keten kumaştan iç gömlek bulmuştur (Onurkan, 1978: 47-48; Onurkan, 1988: 98-100; Aksan, 2015: 306-308).

Doğu Trakya'da bulunan zırhların ikisi MÖ 4. yüzyıla, biri ise MS 1. yüzyıla ait olup tamamı tümülüs buluntusudur.

\section{Miğfer}

Miğfer, insanın en önemli duyularının bulunduğu ve saldırı anında en ölümcül darbelerin alındığı baş kısmını koruyan önemli bir savunma aracıdır. Doğu Trakya'da Eriklice, Naip, Vize A ve Vize E tümülüslerinde miğfer bulunmuşstur (Resim 1).

Eriklice Tümülüsü'nde ${ }^{11}$ tek parça bronzdan yapılmış Khalkidike tipi miğfer ${ }^{12}$ MÖ 5.-4. yüzyıl ortasina tarihlendirilmektedir (Joubin, 1898: 43, No. 273; Hasluck, 1910/1911: 77, No. 273; Onurkan, 1988: 97; Aksan, 2015: 70-75) (Resim 3.1).

Naip Tümülüsü'nde yapılan çalışmalar sırasında bronz miğfere ait parçalar tespit edilmiştir (Resim 3.2). Parçalardan biri volütlü alınlıktır ${ }^{13}$ (Delemen, 2004: 103). Miğfere ait diğer buluntular, olasılıkla sorguç ${ }^{14}$ ile iki şerit ${ }^{15}$ parçasıdır (Delemen, 2004: 104). İnci Delemen alınlık parçası ile diğer buluntuların olasılıkla deriden yapılmış bir miğferin parçaları olduğuna yorumlamıştır (Delemen, 2004: 104-105). Bu parçalar, diğer buluntuların içindeki envanter düşünüldüğünde MÖ 4. yüzyıl sonuna ait olmalıdır. ${ }^{16}$

\footnotetext{
${ }^{11}$ Eriklice Tümülüsü, Kırklareli, Eriklice Köyü’nde bulunduğu kayıtlarda yer almasına karşın maalesef günümüze kadar ulaşamamıştır. 93 Harbi olarak bilinen Osmanl1-Rusya savaşında savunma amaçlı kullanılmak üzere yapılan savunma hattı sırasında 1 Ekim 1891 yılında üzerindeki tüm toprak çekilerek kazısı yapılmış ve sadece mezar yapısı kalmıştır. Daha sonra da mezar yapısı da tamamen yok olmuştur. M. Hristodoulos ve Hasluck'un tarifine göre Kırklareli'nin kuzeybatısında, yaklaşık $1.3 \mathrm{~km}$, Eriklice'nin ise $900 \mathrm{~m}$ kadar doğusunda yer almaktadır (Hristodoulos, 1897: 268-269; Hasluck, 1910/1911: 76-79; Filov, 2013: 31). Eriklice Tümülüsü'nde kazılar sirasında tespit edilen buluntular İstanbul Arkeoloji Müzesi'ne götürülmüştür.

12 İstanbul Arkeoloji Müzeleri'nde 295 envanter numarasıyla korunan miğfer 30,2 cm yükseklinde ve 16,4 cm genişliğindedir (Onurkan, 1988: 97; Aksan, 2015: 71).

${ }_{13}$ Tekirdağ Arkeoloji Müzesi'nde etütlük olarak korunan volütlü alınlık yaklaşık 10,5 cm yüksekliğe ve $43 \mathrm{~cm}$ uzunluğa sahiptir (Delemen, 2004: 103).

14 Tekirdağ Arkeoloji Müzesi'nde etütlük olarak korunan sorguç parçası, $8,8 \mathrm{~cm}$ yüksekliğinde ve 4 ile $7 \mathrm{~cm}$ genişliğindedir (Delemen, 2004: 104).

15 Tekirdağ Arkeoloji Müzesi'nde etütlük olarak korunan şerit parçaları 4,7 ile $7,5 \mathrm{~cm}$ uzunluğundadır (Delemen, 2004: 103).

${ }^{16}$ Tümülüs ve buluntuların tarihi için bk. Delemen, 2004: 113.
} 
DOĞU TRAKYA BULUNTUSU

SAVUNMA VE SALDIRI GEREÇLERİ

Vize A Tümülüsü'nde lahit içerisinde, repoussé tekniğinde yapılmış, genç bir erkeğin portresi şeklinde maske ve bunun menteşe ile tutturulduğu üzerinde saç şeklinde ve farklı bezemeler bulunan başlık kısmından oluşan bir bronz miğfer ${ }^{17}$ bulunmuştur (Resim 3.3). Miğfer MS 1. yüzyıla tarihlendirilmiş̧ir (Mansel, 1940: 100-103; Mansel, 1944: 165-166; Onurkan, 1988: 97-98, No. 102; Aksan, 2015: 302-306).

Vize E Tümülüsü’nde ${ }^{18}$ yoğun şekilde okside olmuş ve üzerinde süvari ile Viktoria kabartması bulunan, MS 1. yüzyıla tarihli demir miğfer yanaklı $\breve{g}_{1}{ }^{19}$ tespit edilmiştir (Mansel, 1939: 461; Onurkan, 1988: 101, No. 104; Aksan, 2015: 386) (Resim 3.4). Aynı tümülüste, yuvarlak biçimli demirden, MS 1. yüzyılın ikinci yarısına tarihlenen miğfer parças $1^{20}$ bir diğer buluntudur (Aksan, 2015: 386-389).

Doğu Trakya'da bulunan toplam beş miğferlerden biri MÖ 5.-4. yüzyıla, ikisi MÖ 4. yüzyıla ve son ikisi MS 1. yüzyıla tarihlenir. Miğferlerin tamamı tümülüslerde bulunmuştur.

\section{Kalkan}

En önemli savunma gereçlerinin başında kalkan gelmektedir. Doğu Trakya'da şu ana kadar üç kalkana ait parça tespit edilmiştir. Bunlar Naip ve Tekhöyük tümülüsleriyle Vakıfiğdemir'de bulunmuş bir parçadan oluşur (Resim 1).

Naip Tümülüsü'nde ahşap yuvarlak kalkanın iç yüzüne ait bronz kaplama tespit edilmiştir ${ }^{21}$ (Resim 4.1). Bronz levhalardan yapılmış kaplama yine bronz çivilerle birleştirilmiştir (Delemen, 2004: 94). Makedon hoplit kalkanın kaplaması İnci Delemen'in yaptığı incelemeler sonucunda MÖ 4. yüzyılın sonuna tarihlendirilmiştir (Delemen, 2004: 94-103).

17 İstanbul Arkeoloji Müzeleri’nde 5730 envanter numarasıyla korunan miğfer $27 \mathrm{~cm}$ yüksekliğindedir (Onurkan, 1988: 98; Aksan, 2015: 302-306).

${ }^{18}$ Vize E Tümülüsü, Kırklareli, Vize İlçesi’nin yaklaşık 6 km güneyinde, Habuğa Köyü'nün yaklaşık 1 km kadar kuzeyinde, ovada yer alır. Arif Müfid Mansel tarafından 1939 yılında kazı gerçekleştirilmiş ve çıkan buluntular İstanbul Arkeoloji Müzesi'ne taşınmıştır.

${ }^{19}$ İstanbul Arkeoloji Müzeleri'nde 5774 envanter numarasıyla korunan miğfer yanaklığı 10,5 cm yüksekliğinde ve 8,4 cm (Onurkan'a göre $16 \mathrm{~cm}$ ) genişliğindedir (Onurkan, 1988: 101; Aksan, 2015: 386).

20 İstanbul Arkeoloji Müzeleri'nde 5775 envanter numarasıyla korunan miğfer parçası 17,3 cm çapındadır (Aksan, 2015: 386-389).

21 Tekirdağ Arkeoloji Müzesi'nde 1944 numarayla envantere kayitlı kalkana ait kaplama levha, uzantısıyla birlikte $67 \mathrm{~cm}$ çapında ve $0,4 \mathrm{~cm}$ kalınlığında, çember çapı $61,3 \mathrm{~cm}$ 'dir (Delemen, 2004: 94). 
Antik Çağ'da kalkanlar ahşaptan yapılmakta, ahşabının üzeri deri kaplanmakta ve demir şeritlerle çerçevelenmektedir. Kalkanın tam ortasında, bazen karşıdan gelen darbeyi hafifletmek için genellikle yarı küresel kalkan göbekleri yerleştirilmektedir (Demirer, 2013: 59). Demir veya bronz gibi farklı metalden yapılmış kalkan göbekleri, daha çok yuvarlak ve oval biçimli kalkanlarda bulunurken, bu tarz kalkanlar da süvariler ve yedek askerler tarafından kullanılmıştır (James, 2004: 165; Oransay, 2006: 96). Doğu Trakya'da iki adet kalkan göbeği bulunmuştur.

Tekhöyük Tümülüsü'nde ${ }^{22}$, üzerinde tekstil ve deri kalıntıları olan demir kalkan göbeğ $i^{23}$ bulunmuştur (Erdoğdu, 1999: 50) (Resim 4.2). Ahşap kalkana ait göbeğin üzerindeki kalıntılardan iç kısmında kumaş ve deri ile birlikte kullanıldığı anlaşılmaktadır. Kalkan göbeği kontekstteki diğer buluntuların da yardımıyla MS 1. yüzyılın 2.-3. çeyreğine tarihlendirilmiştir (Erdoğdu, 1999: 57).

Doğu Trakya'da kalkana ait bir başka parça Malkara'nın Vakıfiğdemir Köyü'nde bulunmuş ve Tekirdağ Arkeoloji Müzesi'nde korunan bronz kalkan göbeğidir ${ }^{24}$ (Resim 4.3). Kalkan göbeğinin kalkana oturduğu düz kısma, sivri bir cisimle vurularak yazı işlenmiştir. Ancak bu yazı okunamamaktadır. ${ }^{25}$ Kalkan göbeğinin benzerleri Arykanda (Oransay, 2006: 96, D34), Dura Europos (James, 2004:173, Fig. 94, 592-594) ve Zeugma (MS 2. yüzy1l) (Alagöz, 2012: Kat. No: 27) ile Zwammerdam'da (MS 2. yüzyıl) (James, 2004: 171) bulunmuştur. Tüm bu örneklere göre değerlendirildiğinde, Vakıfiğdemir Köyü’nde bulunan bu kalkan göbeği MS 2. yüzyıla ait olmalıdır.

Doğu Trakya'da bulunan üç kalkan parçasından Naip Tümülüsü'nde bulunan bronz kalkan kaplaması MÖ 4. yüzyıla, vakıfiğdemir buluntusu bronz kalkan göbeği MS 1. yüzyıla ve Tekhöyük Tümülüsü'nde bulunan demir kalkan göbeği MS 2. yüzyıla tarihlenir.

${ }^{22}$ Tekhöyük Tümülüsü, Tekirdağ, Hayrabolu ilçesi Hacılı Köyü sınırları içerindedir. Kaçak kazı tahribatı nedeniyle 1995 yılında Tekirdağ Arkeoloji Müzesi tarafından kurtarma kazısı gerçekleştirilmiştir.

${ }^{23}$ Tekirdağ Arkeoloji Müzesi'ne etütlük olarak korunan kalkan göbeği 15,5 cm çapında ve 7 cm yüksekliğindedir (Erdoğdu, 1999: 50).

${ }^{24}$ Tekirdağ Arkeoloji Müzeleri'nde 615 envanter numarasıyla korunan kalkan göbeği $21 \mathrm{~cm}$ çapında, 7,5 cm yükseğindedir.

25 Roma İmparatorluk Dönemi kalkan göbekleri üzerinde kalkanı kullanan askerin bağlı bulunduğu lejyon adları veya savaş sırasındaki görevini belirten yazıların kazındığı örnekler bulunmaktadır (görevi belirten örnek için bk. Simkin, 2001: 39). Bu yazı da bu kalkan göbeğinin kullanıldığı lejyon adı olabilir. 
DOĞU TRAKYA BULUNTUSU

SAVUNMA VE SALDIRI GEREÇLERİ

\section{Saldırı Gereçleri}

Doğu Trakya'da savunma gereçlerinin yanında birçok bronz, demir ve kurşun gibi farklı metallerden yapılmış kılıç, mızrak ucu, ok ucu, sapan tanesi gibi saldırı gereçleri de bulunmuştur.

\section{Kılıç}

Saldırı gereci şeklinde kullanılan kılıcın saygınlık gösteren simgesel bir anlamı da bulunmaktadır (Tekin, 2018: 59). Kabza, koruma ve namlu olmak üzere üç bölümden oluşan k1lıçlar bölgesel ve dönemsel farklılık göstermektedir. Doğu Trakya'da Kozman Deresi, Tekhöyük Tümülüsü, Vize A Tümülüsü ve Vakıfiğdemir Köyü'nde bulunmuş kılıç kalıntılarına ulaşılmıştır (Resim 1).

Kozman Deresi Mevkii'nde ${ }^{26}$, bronz kap, tarım aracı ve ingot gibi farklı buluntularının içinde üç adet bronz kılıç da yer almaktadır (Resim 5.1, 2, 3). Kozman Deresi buluntularını yayımlayan Savaş Harmankaya bu kılıçları "Balçıklı Kılıç", "Çift T" ve "Kısa Kılıç/Kama" şeklinde adlandırmıştır ${ }^{27}$ (Harmankaya, 1995: 222-224). Kılıçlar, Savaş Harmankaya tarafından yakın benzerlerine göre MÖ 13.-12. yüzyıllara tarihlendirilmiştir (Harmankaya, 1995: 222-224). ${ }^{28}$

Tekhöyük Tümülüsü'nde yapılan kazı çalışmaları sırasında bir adet demirden yapılmış düz kılıç 29 tespit edilmiştir (Öztürk 1998: 383; Erdoğdu 1999: 49) (Resim 5.4). K1lıç kontekste göre MS 1. yüzyılın 2.-3. çeyreğine tarihlendirilmiştir (Öztürk, 1998: 383; Erdoğdu, 1999: 57).

26 Kozman Deresi, Tekirdağ, Şarköy’e bağlı İğdebağları Köyü’nün yaklaşık $900 \mathrm{~m}$ kuzeydoğusunda, köyün de üzerinde bulunduğu sırtın kuzeydoğusundadır. İğdebağları'ndan bir köylü 1984 yılında alanda silahlar, aletler, süs nesneleri, kaplar ve külçe olmak üzere dört grupta 60 adet eser bulunmuştur. Buluntular, İstanbul Arkeoloji Müzeleri'nde korunmaktadır.

2784.73 envanter numaralı Balçıklı kılıç $38,5 \mathrm{~cm}$ uzunluğunda ve $3 \mathrm{~cm}$ genişliğinde; 84.75 envanter numaralı Çift T kılıç $37,5 \mathrm{~cm}$ uzunluğunda ve 4,4 cm genişliğinde; 84.90 envanter numaralı Kısa Kılıç/Kama ise 37,5 cm uzunluğunda ve 3,3 cm genişliğindedir. Harmankaya tarafindan kılıçların ölçüleri verilmemiş, makale yazarı tarafından çizimler üzerinden ölçüm yapılmıştır.

28 Savaş Harmankaya, tüm kılıçların Son Tunç Çağı'na ait olduğunu belirtmiştir (Harmankaya, 1995: 224).

${ }^{29}$ Tekirdağ Arkeoloji Müzeleri’nde korunan kılıç, $58 \mathrm{~cm}$ uzunluğa, $4 \mathrm{~cm}$ gövde genişliğine, $0,9 \mathrm{~cm}$ gövde kalınlığına; sap kısmı 1,4 cm genişliğe ve 0,8 cm kalınlığa sahiptir (Erdoğdu, 1999: 49). 
Bir diğer k1lıç ise, Vize A Tümülüsü, mezar odasındaki lahit içerisinde parçalar halinde bulunmuştur ${ }^{30}$ (Resim 5.5). Fildişi kabzalı ve ahşap kını ile birlikte bulunmuş bu demir düz kı1ıç, MS 1. yüzyıla tarihlendirilmiştir (Mansel, 1940: 104; Onurkan, 1988: 101; Aksan, 2015: 308-310).

Vakıfiğdemir Köyü'nden bir vatandaş tarafindan Tekirdağ Arkeoloji Müzesi'ne bir adet demir kılıç getirilmiştir ${ }^{31}$ (Resim 5.6). Tek taraflı bu kılıç, kopis/falcata şeklindeki kılıçları andırmakla birlikte yakın benzeri bulunamamıştır. ${ }^{32}$

Doğu Trakya'da beş adet kılıç tespit edilmiştir. Bunlardan üçü Kozman Deresi'nden bronz, ikisi Tekhöyük ve Vize A tümülüslerinden ve biri Vakıfiğdemir Köyü'nden demir kılıçlardır. Kozman Deresi'nde bulunmuş olup MÖ 13. ile 11. yüzyıl arasına, Tekhöyük ve Vize A tümülüs buluntuları MS 1. yüzyıla aittir.

\section{Mozrak Ucu}

Uç kısımları bronz ve demir gibi metalden yapılan mızrakların gövde kısımları ahşaptan yapılmıştır. Mızraklar, yakından kullanıldığı gibi uzak mesafeden firlatılarak da kullanılmıştır.

Kozman Deresi buluntularının içinde üç adet bronz mızrak ucu bulunmaktadır" (Resim 6.1-3). Savaş Harmankaya tarafından "Yarık Kovanlı Üçgen Omuzlu" ve "Yarık Kovanlı Düz Omuzlu" şeklinde adlandırılmıştır ve yakın benzerlerine göre MÖ 12.-11. yüzyıllara tarihlendirilmiştir (Harmankaya, 1995: 224-225).

30 İstanbul Arkeoloji Müzeleri’nde korunan 5732 envanter numaralı kılıç, $80 \mathrm{~cm}$ uzunluğunda, $5 \mathrm{~cm}$ genişliğinde olup, ahşap kını 1,5 cm kalınlığındadır (Onurkan, 1988: 101; Aksan, 2015: 308-310).

${ }^{31} 618$ envanter numaralı tek tarafi keskin kılıç, 46,5 cm uzunluğunda,4,8 cm genişliğinde 0,3 $\mathrm{cm}$ kalınlığındadır. Kabza kısmında organik sapı tutturmak için iki adet $0,4 \mathrm{~cm}$ çapında çivi bulunmaktadır.

${ }^{32}$ K1lıç ile birlikte bir kalkan göbeği (615), iki demir mırak (616 ve 617) ile bir adet at gemi (619) Vakıfiğdemir Köyü’nden Tekirdağ Arkeoloji Müzesi’ne aynı kişi ve yakın tarihlerde getirilmiştir. Olasılıkla bir savaşçı mezarından bulunmuş bu metal buluntular aynı tarihlere ait olması akla gelebilir.

3384.69 envanter numaralı mızrak, kovan kısmından kırık ve eksik şekilde $23,8 \mathrm{~cm}$ uzunluğunda ve $5,2 \mathrm{~cm}$ genişliğindedir. 84.70 envanter numaralı mızrak kovan kısmından kırık ve eksik şekilde $29,3 \mathrm{~cm}$ uzunluğunda $2,4 \mathrm{~cm}$ genişliğindedir. 84.71 envanter numaralı mızrak, ucu üst kısmı kırık ve eksik şekilde $22,3 \mathrm{~cm}$ uzunluğunda, $4,8 \mathrm{~cm}$ genişliğindedir. Harmankaya tarafindan mızrakların ölçüleri verilmemiş, makale yazarı tarafından çizimler üzerinden ölçüm yapılmıştır. 
DOĞU TRAKYA BULUNTUSU

SAVUNMA VE SALDIRI GEREÇLERI

Kartaltepe/Bakacaktepe' de ${ }^{34}$ (Hieron Oros) Tekirdağ Müzesi tarafindan 1985 yılında yapılan kısa süreli kurtarma kazısında birçok demir ok ucuyla birlikte bir adet demir mizrak ucu da tespit edilmiştir ${ }^{35}$ (Resim 6.4). Kartaltepe/Bakacaktepe demir mızrak ucu demir ok uçlarıyla birlikte aynı kontekstte bulunduğundan MÖ 6. yüzyıla tarihlendirilmiştir. ${ }^{36}$

Yündolan C Tümülüsü’ndeki kazılarda, MÖ 4. yüzyıla tarihlenen birçok farklı buluntu ile birlikte ikisi yaprak biçimli toplam sekiz adet demir mızrak parças $1^{37}$ bulunmuştur (Yılmaz, 2001: 76; Yıldırım, 2002: 70-73; Delemen vd. 2010a: 96-97; Delemen vd. 2010b: 7, 10) (Resim 6.6-10). Ancak bu mızrak uçlarının hem şölen ateşine maruz kalması hem de demirin iyi korunamaması nedeniyle çok kötü durumda günümüze ulaşmıştır.

Karaağaçdere (Tatarlı II) Tümülüsü’nde ${ }^{38}$ gerçekleştirilen kurtarma kazısı sırasında takı, pişmiş toprak kandil gibi buluntularla birlikte yaprak biçimli demir mızrak ucu bulunmuştur ${ }^{39}$ (Resim 6.11). Tümülüsdeki kandil gibi pişmiş toprak malzemelerin oluşturduğu kontekste ${ }^{40}$ göre düşünüldügünde, bu mızrak ucu MÖ 4. yüzyıla tarihlendirilmelidir.

Naip Tümülüsü'nde içinde ahşap kalıntıların korunan ve parçalar halinde iki demir mızrak ucu ${ }^{41}$ tespit edilmiş ve MÖ 4. yüzyılın sonuna tarihlendirilmiştir (Delemen, 2004: 107-108) (Resim 6.12-15).

\footnotetext{
${ }^{34}$ Marmara Denizi (Propontis) kıyısında, Hieron Oros/Ganos Dağı'nın en yüksek tepelerinden birinin üzerinde bulunan Kartaltepe/Bakacaktepe, MÖ 5. yüzy1lda önemli ve tahkimli bir kale durumundadır (Koçel-Erdem, 2011: 391).

35 Tekirdağ Arkeoloji Müzesi’nde 1457 envanter numarasıyla korunan mızrak ucu, $16 \mathrm{~cm}$ uzunluğa, $3,1 \mathrm{~cm}$ genişliğe ve $1 \mathrm{~cm}$ kovan çapına sahiptir.

${ }^{36} \mathrm{Bk}$. Kartaltepe/Bakacaktepe demir ok uçları.

${ }^{37} \mathrm{Bu}$ mızrak parçalarının uzunlukları 12 ile $37,7 \mathrm{~cm}$, genişlikleri 2,5 ile 5,2 $\mathrm{cm}$ arasında değişmekle birlikte namlusuyla birlikte tüm şekilde bulunan M13 numaralı mızrak $30.3 \mathrm{~cm}$ uzunluğa ve $3.7 \mathrm{~cm}$ genişliğe sahiptir (Delemen vd. 2010a: 96-97).

${ }^{38}$ Karaağaçdere (Tatarlı II) Tümülüsü, Tekirdağ, Süleymanpaşa'ya bağlı Tatarlı Köyü’nün yaklaşık 600 m kadar kuzeydoğusunda, Karaağaç Deresi'nin hemen kuzeyindeki yamacın güneydoğu eteğinde, Höyüküstü/Karaağaç Dere Mevkiinde yer alır. Tümülüste 1980 yılında Tekirdağ Arkeoloji Müzesi tarafindan kurtarma kazısı gerçekleştirilmiştir.

39 Karaağaçdere (Tatarlı II) Tümülüsü buluntusu demir mızrak ucu Tekirdağ Arkeoloji Müzesi'ne 851 numarayla envantere kayıtlıdır. Mizrak ucu, 37,5 cm uzunluğa, 5,2 cm genişliğe ve $2,5 \mathrm{~cm}$ kalınlığa sahiptir.

40 Karaca, 2019: 203-204, 263-264.

${ }^{41}$ Mızrak uçlarından biri $24.6 \mathrm{~cm}$, diğeri $27 \mathrm{~cm}$ uzunluğundadır.
} 
Tekhöyük Tümülüsü'nde yapılan kazı çalışmaları sıradanında yaprak biçimli iki demir mızrak ucu ${ }^{42}$ tespit edilmiştir (Öztürk, 1998: 383; Erdoğdu, 1999: 48) (Resim 6.16-17). Kılıç ile birlikte bulunan iki mızrak uçlarının altında tekstil kalıntıları tespit edilmiştir (Erdoğdu, 1999: 48). Mızrak uçları kontekste göre MS 1. yüzyılın 2.-3. çeyreğine tarihlendirilmiştir (Öztürk, 1998: 383; Erdoğdu, 1999: 57).

Lalapaşa, Demirköy Tümülüsü'ndeki ${ }^{43}$ mezarda birincil kremasyon uygulanması ve sonraki korunma durumlarından dolayı çok fazla korozyona maruz kalmış, yaprak biçimli iki demir mızrak ucu ${ }^{44}$ tespit edilmiştir (Resim 6.18-19). Mezar içerisinde bulunan diğer buluntular; bir adet bronz sikke, bronz parçalar, demir çiviler ile birlikte libasyon amaçlı kırılmış MS 1. yüzyıla tarihlenen seramiktir (Çokaman ve Kırçın, 2015: 73-75; Çokaman ve Kırçın, 2016: 150; Batur, 2021 48-51). İki demir mızrak ucu diğer buluntularla birlikte düşünüldüğünde MS 1. yüzyıla ait olmalıdır.

İkiztepe B Tümülüsü'nde ${ }^{45}$ kremasyon mezarı içinde, MS 1. yüzyıla tarihlenen birçok farklı buluntu ile birlikte iki adet demir mızrak ucu tespit edilmiştir (Yıldırım, 2007: 88-90; Yıldırım, 2012: 55, dipnot 196; Batur, 2021: 44) (Resim 6.20-21). Mızrak uçlarından ilki, mezarın kuzeyinde deri kılıflı ve üzerinde küçük çivilerin bulunduğu sapa ait ahşap parça ile ikinci bir mızrak mezarın güneyinde aynı yerde tespit edilmiştir (Yıldırım, 2007: 89-90; Yıldırım, 2012: 55, dipnot 196). Mezarın kuzey batısına ise, ahşap saplı altı parça halinde bulunmuş demir bir hançer ${ }^{46}$ bırakılmıştır. Ancak mızrak uçları ve hançer oldukça kötü durumdadır (Yıldırım, 2007: 89; Yildırım, 2012: 55, dipnot 196).

42 Tekirdağ Arkeoloji Müzesi'nde etütlük olarak korunan mızrak uçlarından ilki $44 \mathrm{~cm}$ uzunluğa, $5,2 \mathrm{~cm}$ genişliğe ve $2,5 \mathrm{~cm}$ sap çapına; ikincisi $42 \mathrm{~cm}$ uzunluğa, $5,8 \mathrm{~cm}$ genişliğe ve 2,3 cm sap çapına sahiptir (Erdoğdu, 1999: 48).

${ }^{43}$ Demirköy Tümülüsü, Edirne, Lalapaşa' ya bağlı Demirköy içinde bulunur. Kaçak kazılar sonucu tahrip olan tümülüs Edirne Arkeoloji Müzesi tarafindan 2013 y1lında kurtarma kazıs1 gerçekleştirilmiştir.

${ }^{44}$ Edirne Arkeoloji Müzesi'nde etütlük olarak korunan mızrak uçlarından ilki, 18,2 cm uzunluğunda ve 4,6 cm genişliğindedir. İkinci mızrak ucu 15,4 cm uzunluğunda ve $4,1 \mathrm{~cm}$ genişliğindedir. Mızraklar ile ilgili bilgilerini paylaştığı için Ark. Şahan Kırçın’a teşekkür ederim.

45 İkiztepe B Tümülüsü, Edirne, Lalapaşa'ya bağlı Çömlekakpınar Köyü’nün 2 km. kadar kuzeyindedir. Tümülüs, 2004 yılında Edirne Arkeoloji Müzesi tarafindan kazılmıştır.

46 Edirne Arkeoloji Müzesi'nde etütlük olarak korunan hançer $30 \mathrm{~cm}$ uzunluğundadır (Y1lırım, 2012: 55, dipnot 196). 


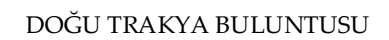

SAVUNMA VE SALDIRI GEREÇLERİ

Vize A Tümülüs'ündeki mezar odasında bulunan lahit içerisinde, okside olmuş ve kovan kısımları parçalı şekilde iki adet demir mızrak ucu ${ }^{47}$ bulunmuş ve bunlar MS 1. yüzy1la tarihlendirilmiştir (Mansel, 1940: 104 Lev.41, Res.32b; Onurkan, 1988: 102, No.106, 107; Aksan, 2015: 310-312, Res. 385-386) (Resim 6.22-23).

Vize E Tümülüs'ünde mezar içinde üç adet demir mizrak ucu ${ }^{48}$ bulunmuştur (Mansel, 1939: 461; Aksan, 2015: 384-386) (Resim 6.24-26). Üç demir mızrak ucu diğer buluntularla birlikte MS 1.yüzyılın son çeyreğine tarihlenmektedir (Aksan, 2015: 397-400).

Vize, Vezirtepe Tümülüsü'nde ${ }^{49}$ birçok pişmiş toprak kap ve bronz kaplarla birlikte iki demir mızrak ucu bulunmuştur ${ }^{50}$ (Resim 6.27-29). Vezirtepe Tümülüs'ünde bulunan bronz kandil, bronz kaplar ile birlikte değerlendirildiğinde MS 1. yüzylla tarihlendirmek mümkündür.

Dolucatepe' $\mathrm{de}^{51}$ bir adet demir mizrak ucu bulunmuştur ${ }^{52}$ (Resim 6.30). Vezirtepe Tümülüsü'nde bulunan üç mızrak ucu ile benzer Dolucatepe buluntusu mızrak ucu da MÖ 1. yüzyıla ait olmalıdır.

Yukarıda bahsedilen bronz kalkan göbeği ve demir kılıç ile birlikte, Vakıfiğgdemir Köyü'nden iki adet demir mızrak ucu da Tekirdağ Arkeoloji Müzesi'ne gelmiştir ${ }^{53}$ (Resim 6.31-32). Dolucatepe'de ve Vezirtepe

\footnotetext{
47 İstanbul Arkeoloji Müzeleri'nde korunan 5733 envanter numaralı mizrak ucu 32,5 cm uzunluğa, $5 \mathrm{~cm}$ genişliğe ve $2,2 \mathrm{~cm}$ kovan genişliğine; 5734 envanter numaralı mızrak ucu ise, $40 \mathrm{~cm}$ uzunluğa, 4,6 cm genişliğe ve 2,1 cm kovan çapına sahiptir (Onurkan, 1988: 102; Aksan, 2015: 310-311).

48 İstanbul Arkeoloji Müzeleri'nde korunan 5776 envanter numaralı mızrağın kovan kısmı kırık ve eksik olup yaklaşık $40 \mathrm{~cm}$ uzunluğa; üç parça halinde bulunan 5777 envanter numaralı mızrak yaklaşı $25 \mathrm{~cm}$ uzunluğa; etütlük şeklinde kaydedilen üçüncü mızrak parçası ise 23,6 uzunluğa ve 3,5 kovan çapına sahiptir (Aksan, 2015: 384-386).

49 Vezirtepe Tümülüsü, Kırklareli, Vize'ye bağlı Kıyıköy Beldesi'nin yaklaşık $1.5 \mathrm{~km}$ batısında bulunur. Buradaki buluntular Tekirdağ Arkeoloji Müzesi'nde koruma altındadır.

50 Tekirdağ Arkeoloji Müzesi'nde korunan 1582 envanter numaralı mizrak ucu 45,7 cm uzunluğa ve $6 \mathrm{~cm}$ genişliğe; 1583 envanter numaralı mızrak ucu 44,5 uzunluğa ve $6,1 \mathrm{~cm}$ genişliğe sahiptir.

51 Dolucatepe, Marmara Denizi (Propontis) kıyısında, Tekirdağ, Şarköy İlçesi, Tepeköy'ün yaklaşık 1.5 km kuzeybatısında bulunmaktadır. Bk. Koçel-Erdem, 2010: 310; Karaca, 2019: 210-211.

52 Tekirdağ Arkeoloji Müzesi'nde 1999 envanter numarasıyla korunan mizrak ucu, 36,8 cm uzunluğa, $4,5 \mathrm{~cm}$ genişliğe ve $2 \mathrm{~cm}$ kovan çapına sahiptir.

${ }^{53}$ Vakıfiğdemir Köyü'nden gelmiş iki demir mızrak ucu, Tekirdağ Arkeoloji Müzesi'nde 616 ve 617 envanter numarasıyla korunmaktadır. 616 numaralı mizrak ucu $37,5 \mathrm{~cm}$
} 
Tümülüs'ünde bulunan demir mızrak uçları ile Vakıfiğgemir mızrak uçları benzer olmalarından dolayı MS 1. yüzyıla tarihlendirmek mümkündür.

Doğu Trakya'daki ok uçlarından sonra ikici yoğun grubu mızrak uçları oluşturmaktadır. En erken mızrak ucu, Kozman Deresi'nde bulunmuş ve MÖ 13.-11. yüzyıllara tarihlendirilmiştir. Diğer mızrak uçları MÖ 4. yüzyıl ve MS. 1. yüzyıla şeklinde iki dönemde yoğunlaşttğ 1 görülmektedir. Yündolan C Tümülüs'ünde bulunan sekiz, Karaağaç Tümülüs'ündeki bir mızrak ucu hariç tümülüs buluntusu mızrak uçlarının ikişerli set halinde mezara bırakıldığ görülmektedir. Bu durumun mezara birakılan hediye kültürü ile alakalı olduğu kabul edilmektedir. ${ }^{54}$ Tekhöyük Tümülüs'ünde bulunan kılıç, mızrak uçları ile kalkanda tespit edilen tekstil kalıntıları savaş gereçlerinin bir beze sarılarak veya bir bezin üzerinde mezara bırakıldıklarını düşündürmektedir.

\section{Ok Ucu}

Antik Çağ'da okun uç kısmı hariç gövdesi organik malzemeden yapılmaktadır. Bu nedenle de bronz, demir gibi madenlerden yapılmış ok uçları günümüze ulaşmaktadır.

Silivri’de Cambaztepe Tümülüsü'nün ${ }^{55}$ ikincil kullanımında, MÖ 3. binyıla tarihlenen kurganın üzerine, olasılıkla MÖ 1. binyılda yapılan bir definde bronz iğne ile birlikte bronz ok ucu tespit edilmiştir (Polat 2016: 236).

Kartaltepe/Bakacaktepe'de yukarıda bahsedilen demir mizrak ucu ile birlikte 16 adet demir ok ucu bulunmuştur. Burada bulunan demir ok uçlarının en yoğun iki grubunu, dokuz ok ucu ile kesici ve delici ucu dörtgen kesitli piramidal ve saplamalı olanlar oluşturmaktadır ${ }^{56}$ (Resim 7.1-9). Diğer

uzunluğunda, 5,1 genişliğinde ve 1,9 cm kovan çapına sahiptir. 616 numaralı mızrak ucu $37,5 \mathrm{~cm}$ uzunluğunda, $4,5 \mathrm{~cm}$ genişliğinde, $1 \mathrm{~cm}$ kovan çapına sahiptir.

${ }^{54}$ Mezara iki adet mızrak konulmasıyla ilgili ayrıntılı bilgi için bk. Delemen, 2004: 108-109.

55 Cambaztepe Tümülüsü (Kurgan), Silivri, Çanta Mahallesi'nde yer almaktadır. Adı geçen tümülüsde İstanbul Arkeoloji Müzeleri tarafından kurtarma kazısı gerçekleştirilmiştir.

56 İlk grupta yer alan 1429 numaralı ok ucu $5,5 \mathrm{~cm}$ uzunluğa, $0,5-1 \mathrm{~cm}$ kalınlığa ve 10,15 gr ağırlığa; 1435 numaralı ok ucu $6 \mathrm{~cm}$ uzunluğa, 0,3-1 cm kalınlığa ve 12,35 gr ağırlığa; 1436 numaralı ok ucu 5,8 cm uzunluğa, 0,3-0,4 cm kalınlığa ve 11,40 gr ağırlığa; 1438 numaralı ok ucu 5,9 cm uzunluğa, 0,3-1,2 cm kalınlığa ve 11,35 gr ağırlığa; 1439 numaralı ok ucu 5,4 cm uzunluğa, 0,4-1 cm kalınlığa ve 11,85 gr ağırlığa; 1440 numaralı ok ucu 7,6 cm uzunluğa, 0,3-1,3 cm kalınlığa ve 12,80 gr ağırlığa; 1441 numaralı ok ucu $6,6 \mathrm{~cm}$ uzunluğa, 0,4-1 cm kalınlığa ve 11,80 gr ağırlığa; 1442 numaralı ok ucu 5,7 cm uzunluğa, $0,3-0,9 \mathrm{~cm}$ kalınlığa ve 10 gr ağırlığa; 1443 numaralı ok ucu $6,8 \mathrm{~cm}$ uzunluğa, $0,3-1 \mathrm{~cm}$ kalınlığa ve 10,60 gr ağırlığa; 1444 numaralı ok ucu $6,6 \mathrm{~cm}$ uzunluğa, 0,3-0,9 kalınlığa ve 7,60 gr 


\section{DOĞU TRAKYA BULUNTUSU}

SAVUNMA VE SALDIRI GEREÇLERİ

bir grup ise, kesici ve delici ucu dörtgen kesitli piramidal ve kovanl1 ${ }^{57}$ beş adet ok ucudur (Resim 7.10-14). Her iki gruptaki demir ok uçları MÖ 6. yüzyıla tarihlendirilmiştir. ${ }^{58} \mathrm{Bu}$ iki grubun haricinde iki adet demir ok ucu bulunmaktadır. İlk demir ok ucu kanatlı, kanatlar saplama kısmına doğru mahmuzludur $^{59}$ (Resim 7.15). Diğer demir ok ucu saplamalıdır ${ }^{60}$ (Resim 7.16). Her iki demir ucu MÖ 6. yüzyıla tarihlendirmek mümkündür. ${ }^{61}$

Heraion Teikhos ${ }^{62}$ kazılarında 22 âdeti bronz, yedisi demir olmak üzere toplam 29 adet ok ucu Akropol kısmında Kuzey Kapısı, Hellenistik Dönem Nekropolü, Kült ve Tedavi merkezi, Hera/Kybele Kutsal Alanı ile atölyeler sektörlerinde bulunmuştur (Atik, 2017: 58-60). Heraion Teikhos'da

ağırlığa sahiptir. Bu grupta yer alan demir ok uçlarının benzerleri Daniş Baykan tarafından Nif Dağı, Karamattepe ve Ballıcaoluk buluntuları Nif Tip 1 şeklinde adlandırılmıştır. Bk. Baykan 2017: 24.

${ }^{57}$ İkinci grupta yer alan 1430 numaralı demir ok ucu $7 \mathrm{~cm}$ uzunluğa, 0,3-1,4 cm kalınlığa ve 24,60 gr ağırlığa; 1431 numaralı demir ok ucu 8,7 cm uzunluğa, 0,5-1,5 kalınlığa ve 32,30 gr ağırlığa; 1432 numaralı demir ok ucu $6,4 \mathrm{~cm}$ uzunluğa ve $0,5-1,5 \mathrm{~cm}$ kalınlığa; 1433 numaralı demir ok ucu $6,2 \mathrm{~cm}$ uzunluğa, $0,5-1,5 \mathrm{~cm}$ kalınlığa ve 20,70 gr ağırlığa; 1434 numaralı demir ok ucu $8,2 \mathrm{~cm}$ uzunluğa, $0,3-1,8 \mathrm{~cm}$ kalınlığa ve 40,50 gr ağırlığa sahiptir. $\mathrm{Bu}$ grupta yer alan demir ok uçlarının benzerleri Daniş Baykan tarafından Nif Dağı, Karamattepe ve Ballıcaoluk buluntuları Nif Tip 2 şeklinde adlandırılmıştır. Bk. Baykan 2017: 25.

$58 \mathrm{Bu}$ ok uçlarının tarihlemesi oldukça tartışmalıdır. MÖ 6. yüzyıldan MS 6.-7. yüzyıla kadarki süreçte tarihlenmektedir. Genelde bulundukları kontekst ve ağırlıklarına göre tarihlendirilmektedir. Benzerleri MÖ 6. yüzyılın ikinci yarısına tarihli Nif Dağı Karamattepe'de (Baykan, 2017: 33), MÖ Geç 6.- Erken 5. yüzyıl tarihli Kolonos Tepesi’nde (Thermopylai) (Kakavas, 2013: 119, Kat. No 99-100), MÖ 4. yüzyıla tarihli Olynthos'ta (Robinson, 1941: 392-397, Lev. CXXXIII, CXXXIV), MÖ 2. yüzy1l ile MS. 1 yüzylllara tarihli Heraion Teikhos'da (Atik, 2017: 70-71, 73-75), biri Roma Dönemi olabileceği belirtilmekle birlikte MÖ 1. yüzyıla tarihli Fatsa Cingırt Kalesi'nde (Erol ve Yıldırım, 2016: Kat. No. 06, 07, 08), MÖ 1. yüzyıla tarihli Olba'da (Akçay, 2018: 115, Kat. No. 06), kesin olmamakla birlikte Korinth'te MS 6.-7. yüzy1llara (Davidson, 201-202, Pl. 93, 1532, 1540, 1558) benzerleri tarihlendirilmiștir. Aynı kontekstte bulunan Bakacaktepe buluntusu demir ok uçlarını Daniş Baykan fotoğraflardan ve ağırlık verilerine göre MÖ 6 . yüzyıl olması gerektiğini belirtmiş̧ir.

591437 numaralı demir ok ucu 7,9 cm uzunluğa, 1,6 cm genişliğe, 0,6 cm kalınlığa ve 14,50 gr ağırlığa sahiptir.

${ }^{60} 1445$ numaralı üs kısmı kırık demir ok ucu 8,8 cm uzunluğa, 2,1 genişliğe ve $0,5 \mathrm{~cm}$ kalınlığa sahiptir.

${ }^{61}$ Demir ok uçlarının tarihlemesi için Daniş Baykan'a teşekkür ederim.

${ }^{62}$ Heraion Teikhos, Tekirdağ, Karaevli Köyü’nün yaklaşık 4 km güneydoğusunda, Marmara Denizi kıyısında Karaevlialtı (Körfez) Mevkii'nde yer almaktadır. Kentte Neşe Atik başkanlığında kazı çalışmaları gerçekleştirilmektedir. 
bulunmuş, bronz ve demirden yapılmış ok uçları ${ }^{63}$, "iki ve üç kanatlı", "gövdesi kare kesitli ve saplamalı", "gövdesi yassı baklava kesitli", "kanat uçları mahmuzlu ve saplamalı", "üç kanatlı ve saplamalı" şeklinde sınıflandırılmıştır (Atik, 2017: 62-71) (Resim 7.17-24). Bronz ok uçlarını Kült Alanı ve Tedavi merkezinde bulunanlar MÖ 1. yüzyıl ile MS 1. yüzyıl arasına, Kuzey Kapısı, Hera/Kybele Kutsal Alanı ile atölyelerde bulunanlar MÖ 6. yüzyıl ile MÖ 2. yüzyıl arasında tarihlendirildiği görülmektedir (Atik, 2017: 52-69, 71-73). Demir ok uçları ise, Hera/Kybele Kutsal Alanı ile Kuzey Kapısı yakınlarında bulunmuş ve MÖ 2. yüzyıl-MS 1. yüzyıl arasına tarihlendirilmiştir (Atik, 2017: 69-71, 73-74).

Ainos, Suterazisi Nekropolü'nde yapılan kazılar sırasında iki kanatlı ve kabaralı şeklinde tanımlanan bir adet ok ucu bulunmuştur (Baş, 2019: 2526). Bu ok ucu olasılıkla MÖ 4.-2. yüzyıllara tarihlenmektedir. ${ }^{64}$

Yukarıda belirtilen ok uçlarının haricinde, Edirne ve Tekirdağ Arkeoloji müzelerine satın alma yoluyla farklı noktalardan getirilmiş ok uçları da bulunmaktadır. Bunların bazen buluntu yeri belirtilmiş olsa çoğunlukla belli değildir. ${ }^{65}$ Edirne Arkeoloji Müzesi'nde Hıdırağa Köyü, Pınarhisar, Keşan ve Tekirdağ' dan gelen dört ok ucu bulunmaktadır. ${ }^{66} \mathrm{Bu}$ ok uçlarının erken örneği Edirne'ye bağlı Hıdırağa Köyü'nden gelmiştir (Resim 7.25). Sivri kanatlı yassı şekildeki bronz ok ucu, benzerlerine göre MÖ 10.-8. yüzy1la tarihlendirilmiştir (Baş, 2019: 46-47, Kat. No. 21; Baş, 2021: 11, Kat. No. 10). Kırklareli, Pınarhisar'da bulunmuş, iki kanatlı, mahmuzlu ve kovanlı bronz ok ucu MÖ 7.-6. yüzyıllara tarihlendirilmiştir (Baş, 2019: 47-48, Kat. No. 22; Baş, 2021: 11-12, Kat. No. 11) (Resim 7.26). Edirne, Keşan'da bulunmuş baklava biçimli kesitli ve saplı bronz ok ucu MÖ 2. yüzyıl-MS 1 . yüzy1l arasına tarihlendirilmiştir (Baş, 2019: 49-50, Kat. No. 23; Baş, 2021: 12-13, Kat. No. 12) (Resim 7.27). Tekirdağ' da bulunduğu belirtilen dörtgen

63 İki ve üç kanatlı bronz ok uçlarının uzunlukları $2 \mathrm{~cm}$ ile $8,1 \mathrm{~cm}$ arasında; gövdesi kare kesitli ve saplamalı, gövdesi yassı baklava kesitli, kanat uçları mahmuzlu ve saplamalı, üç kanatlı ve saplamalı demir ok uçlarının uzunlukları $3,7 \mathrm{~cm}$ ile $6,9 \mathrm{~cm}$ arasında, $1,2 \mathrm{~cm}$ ile 2 cm kanat genişliğine sahiptir (Atik, 2017: 62-71).

${ }^{64}$ Ainos buluntusu bu ok ucu ile ilgili bilgilerini paylaştığ için Didem Baş'a teşekkür ederim.

${ }^{65}$ Genelde Tekirdağ gibi veya Keşan, Pınarhisar gibi ilçe isimleri ok uçlarının geliş yeri olarak kayit edilmiştir.

${ }^{66}$ Edirne Arkeoloji Müzesi'nde korunan 782 envanter numarasıyla kayıtlı ok ucu 5,3 cm uzunluğa, 2,5 cm genişliğe ve 3,94 gr ağırlığa; 2495 envanter numarasıyla kayıtlı ok ucu 4,8 cm uzunluğa, 1,2 cm genişliğe ve 5,45 gr ağırlığa; 1334 envanter numarasıyla kayıtlı ok ucu $8,3 \mathrm{~cm}$ uzunluğa, $1,3 \mathrm{~cm}$ genişliğe ve 12,38 gr ağırlığa; 435 envanter numarasıyla kayıtlı ok ucu ise, $6 \mathrm{~cm}$ uzunluğa, $0,8 \mathrm{~cm}$ genişliğe ve 5.84 gr ağırlığa sahiptir (Baş, 2019: Kat. No. 21-24; Baş, 2021: Kat. No. 10-13). 
DOĞU TRAKYA BULUNTUSU

SAVUNMA VE SALDIRI GEREÇLERİ

kesitli, iki kanatlı ve saplı bronz ok ucu MÖ 1. yüzyıl ile MS 2. yüzy1l arasına tarihlendirilmiştir (Baş, 2019: 50, Kat. No. 24; Baş, 2021: 13-14, Kat. No. 13) (Resim 7.28). Gelibolu, Çokal Köyü’nden Tekirdağ Arkeoloji Müzesi'ne gelmiş bir bronz ok ucu da bulunmaktadır ${ }^{67}$ (Resim 7.29). Bu ok ucunu yakın benzerlerine göre MÖ 4.-2. yüzyıla tarihlemek mümkündür. ${ }^{68}$

Doğu Trakya'da ele geçen savunma ve saldırı aletleri içerisinde en yoğun grubu ok uçları oluşturmaktadır. Bunların en erkeni, MÖ 10.-8. yüzyıla tarihlendirilen Hıdırağa ve en geç tarihlendirileni ise, MÖ 1. ile MS. 2. yüzyıl arasına tarihlendirilen Tekirdağ buluntusu ok ucudur.

\section{Sapan Tanesi}

Etkisi bakımında ok ile neredeyse bir kullanıma sahip sapan taneleri, Antik Çağ' da savaş ve av faaliyetlerinde sıklıkla kullanılmıştır. Bu nedenle pek çok farklı yerde sapan tanelerine rastlanmaktadır. Doğu Trakya'da Heraion Teikhos'da kazı buluntusu şeklinde ve Büyük Anafarta Köyü'nden Çanakkale Arkeoloji Müzesi'ne, Pınarhisar'dan ise Edirne Arkeoloji Müzesi'ne bağış şeklinde gelmiş örnekler bulunmaktadır.

Heraion Teikhos, Kale Kuzey kapısı yakındaki kazılarda ok ve mızrak uçları ile birlikte birçok kurşun sapan tanesi de bulunmuştur (Resim 8.1). Üzerinde akrep kabartması bulunan sapan tanesi ile diğer kazı buluntusu sapan taneleri kontekste göre MÖ 6. yüzylla tarihlendirilmiştir (Atik, 2016: 79; Atik, 2017: 59).

Çanakkale, Gelibolu, Büyük Anafarta Köyü, olasılıkla Alopekonnesos kentinin bulunduğu Küçükkemikli Burnu ve civarından Çanakkale Müzesi'ne dört adet ovoid biçimli kurşun sapan tanesi gelmiştir. İki sapan tanesinden birinin üzerinde tam belli olmamakla birlikte üzerlerinde bir merkezden çıkan üç bacak (triskeles) bulunmaktadır ${ }^{69}$ (Resim 8.2-3).

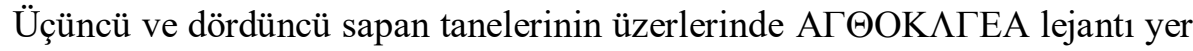

\footnotetext{
67 Tekirdağ Arkeoloji Müzesi'nde 1878 envanter numarasiyla korunan ok ucu 4,1 cm uzunluğa ve $1,6 \mathrm{~cm}$ genişliğe ve 12,70 gr ağırlığa sahiptir.

${ }^{68}$ Çokal Köyü'nde bulunan ok ucunun benzerleri birçok farklı merkezde bulunmuştur. Heraion Teikhos (Atik, 2017: 61-65, MÖ 2. yüzyıl), Nif Dağı, Karamattepe (Baykan, 2017, 31), Korinthos (Davidson, 1952: Pl. 91, 1513-1514, MÖ 4. yüzyıl), Delos (Deonna, 1938: 208, Pl. LXIX, 556) bu merkezlerden bazılarıdır.

${ }^{69}$ Çanakkale Arkeoloji Müzesi'nde korunan 2350 ve 2360 envanter numaralı kurşun sapan taneleri $3 \mathrm{~cm}$ uzunluğa ve $1,5 \mathrm{~cm}$ genişliğine sahiptir.
} 
almaktadır $^{70}$ (Resim 8.4-5). Gerek üzerindeki betim gerekse lejantlara göre düşünüldüğünde kurşun sapan taneleri MÖ 4.-2. yüzyıllara tarihlendirilmektedir.

Edirne Arkeoloji Müzesi'nde, Kırklareli'ne bağlı Pınarhisar İlçesi'nden üç adet kurşun sapan tanesi bulunmaktadır ${ }^{71}$ (Resim 8.6-8). Ovoid biçimli bu sapan taneleri MÖ 4.-2. yüzyıla arasına tarihlendirilmiştir (Baş, 2019: 53, Kat. No. 26, 27, 28; Baş, 2021: 14).

Doğu Trakya'da kazısı yapılan Heraion Teikhos kazısında birçok MÖ 6. yüzyıla tarihlenen kurşun sapan tanesi bulunmuştur. Bunların yanı sıra bölge müzelerinde de kurşun sapan tanesi bulunmaktadır. Edirne Arkeoloji Müzesi'ne Pınarhisar'dan, Çanakkale Arkeoloji Müzesi'ne ise Büyük Anafarta Köyü'nden MÖ 4. ile 2. yüzyıl arasına tarihlenen yedi adet sapan tanesi gelmiştir. Bölgede bulunan bir diğer saldırı aracı ise, sapan tanelerdir. Büyük Anafarta Köyü'nden gelen iki sapan tanesi üzerindeki bulunan

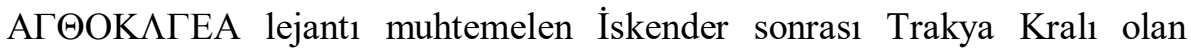
Lysimakhos'un oğlu Agathokles (A $\gamma \alpha \theta$ oк $\lambda \tilde{\eta} \varsigma)$ adıdır ve onun ordusundaki askerlerin kullandığı sapan taneleri olmalıdır.

\section{Sonuç}

Doğu Trakya'da bulunmuş savunma ve saldırı gereçlerine baktığımızda bunların büyük çoğunluğunun tümülüslerde bulunduğu görülmektedir (Tablo 1). Bunun nedenlerinden biri, mezar hediyesi olarak savaşçıların tümülüslerine silah bırakma geleneğinin olmasıdır. Ancak burada bir başka nokta yerleşim kazılarının az olması da göz önünde bulundurulmalıdır.

Savunma ve saldırı gereçlerinin kendi içlerindeki zamansal dağılımı oldukça önemlidir. Savunma gereçlerinden zırhlardan biri MS 1. yüzyıl, diğer ikisi MÖ 4. yüzyıl; miğferlerden ikisi MS 1. yüzyıl, diğer üçü MÖ 5.4. yüzyıl; kalkan ve kalkan parçaları ise MÖ 4. yüzyıl, MS 1. yüzyıl ve MS 2. yüzyıl şekilde eşit dağıldığ görülür (Tablo 2). Saldırı gereçlerinde ise, kılıçlarda MÖ 13.-12 yüzyıl ile MS 1. yüzyılın; mızrak uçlarında MS 1. yüzyılın en yoğun dönemi oluşturduğu ve bunu MÖ 4. yüzyılın takip ettiği; ok uçlarında en yoğun grubu MÖ 6. yüzyılın oluşturduğu, bunu MÖ 4.

${ }^{70}$ Çanakkale Arkeoloji Müzesi'nde korunan 2369 envanter numaralı sapan tanesi 3,5 cm uzunluğunda ve $2 \mathrm{~cm}$ genişliğindedir. 2370 envanter numaralı sapan tanesi $2,5 \mathrm{~cm}$ uzunluğa ve $2 \mathrm{~cm}$ genişliğe sahiptir.

71 Edirne Arkeoloji Müzesi'nde korunan 2491 envanter numaralı sapan tanesi $3,1 \mathrm{~cm}$ uzunluğa ve 1,7 cm genişliğe; 2492 envanter numaralı sapan tanesi $2,8 \mathrm{~cm}$ uzunluğa ve 1,5 $\mathrm{cm}$ genişliğe; 2493 envanter numaralı sapan tanesi $3,3 \mathrm{~cm}$ uzunluğa ve $1,7 \mathrm{~cm}$ genişliğe sahiptir. 
DOĞU TRAKYA BULUNTUSU

SAVUNMA VE SALDIRI GEREÇLERİ

yüzyıl ile MÖ 2. yüzyıllar takip ettiği; sapan tanelerinde MÖ 4.-2. yüzyılın yoğun olduğu görülür (Tablo 3).

Tüm Doğu Trakya savunma ve saldırı gereçlerine kronolojik şekilde incelendiğinde, üç dönemin ön plana çıktığı görülür: Bunlardan ilki MÖ 6. yüzyıl, ikincisi MÖ 4. yüzyıl, üçüncüsü ise MS 1.-2. yüzyıldır. Bu üç tarih bize MÖ 6. yüzyıldaki Pers, MÖ 4. yüzyıldaki Makedon ve sonuncusu ise MÖ 1. yüzyıldaki Roma İmparatorluğu dönemi idareleriyle bağlant1lı gözükmektedir. Pers Büyük Kralı I. Darios, MÖ 513 yılındaki İskit Seferi'nden dönüşünde Megabazos'u Trakya'yı ele geçirmekle görevlendirmiş, o da ilk önce Perinthos'u ele geçirmiş ve daha sonra bölgede tam anlamıyla egemenliği sağlamıştır (Herodotos, V. 1-2). Bakacaktepe'de ${ }^{72}$ bulunan ve MÖ 6. yüzyıla tarihlenen demir ok uçları bu açıdan oldukça önemlidir. Olasılıkla Megabazos Perinthos'a doğrudan saldırmadan önce onun çevresinde, hatta onun kontrolünde bulunan kale yerleşilmelerini ele geçirmiş olmalıdır. Bu sırada Bakacaktepe'ye de saldırmış olması ihtimal dâhilindedir. Doğu Trakya savunma ve saldırı gereçlerinin tarihlemesinde en yüksek olduğu dönem ise MÖ 4. ve 3. yüzyıldır. Bu dönem ise Makedon Kralı II. Philppos'un MÖ 4. yüzyı1 ortasından itibaren bölgede hâkimiyet kurması, ondan sonra gelen ardıllarının da bu hâkimiyeti pekiştirmesinin bir sonucudur. Buluntuların tarihlemesine göre son dönem ise MS 1. ve 2. yüzyılda bölgenin tamamen Roma İmparatorluğu hâkimiyetine girmesi, özellikle de MS 1. yüzyılda bölgenin Trakya Eyaleti olmasından sonra hâkimiyetinin yoğunlaştığını göstermesi açısından önemlidir.

$\mathrm{Bu}$ makaleden elde edilen bir diğer sonuç ise, mevcut verilere göre en azından Doğu Trakya'da bulunan saldırı ve savunma gereçlerinin yerel halk olarak kabul edebileceğimiz Traklar ile bağlantısının olmadığı, daha çok MÖ 6. yüzyıldan itibaren bölgeyi hâkimiyetleri altına alan büyük krallıkların veya imparatorluklara ait olmasidır.

\section{Teşekkür}

Edirne, Tekirdağ ve Çanakkale müzelerinde yapıtlığım araştırmalarda yardım ve desteklerini esirgemeyen müze müdürleri ile uzmanlarına, Daniş Baykan, Şahin Yıldırım, Şahan Kırçın, Diden Baş, Gülay Meriç, Hacı Yağuzluk, Sevtap Gölgesiz Karaca ile yayınlarını kullandığım tüm araştırmacılara sonsuz teşekkür ederim.

\footnotetext{
72 Bakacaktepe, MÖ 1. Binyılda Propontis kıyısında önemli kale yerleşimlerinden biridir. Makedon Kralı II. Philppos'un MÖ 350 civarında Trak Kralı Kersoleptes'i burada kuşatmış, fakat bu kuşatma başarısızlıkla sonuçlanmıştır. Bk. Demosthenes VII 37; IX 15; XIX 334; Sayar, 1993: 156; Koçel-Erdem, 2009: 420-421; Koçel-Erdem, 2010: 310.
} 


\section{Resim ve Tablo Listesi}

Resim 1: Doğu Trakya Buluntusu Savunma ve Saldırı Gereçlerinin Ele Geçtiği Merkezler (Yazar tarafindan oluşturulmuştur)

Resim 2: Yündolan C Tümülüsü Zırh Plakaları (1) (Delemen vd. 2010b: Res. 4), Naip Tümülüsü Zırha Ait Levha ve Halkalar (2) (Delemen, 2004: fig. 105, 106, 107, 108), Vize A Tümülüsü Zırh ve Çizimi (3-4) (Aksan, 2015: Res. 382, Omurkan, 1988: Şek. 50)

Resim 3: Eriklice Tümülüsü Miğfer (1) (Aksan, 2015: Res. 57), Naip Tümülüsü Miğfer Parçaları (2) (Delemen, 2004: fig. 102, 103, 104), Vize A Tümülüsü Miğfer (3) (Aksan, 2015: Res. 377), Vize E Tümülüsü Miğfer Parçası (4) (Aksan, 2015: Res. 479)

Resim 4: Naip Tümülüsü Kalkan Parçası (1) (Delemen, 2004: fig. 93), Tekhöyük Tümülüsü Kalkan Göbeği Parçaları ve Çizimi (2) (Ölçeksiz) (Erdoğdu, 1999: Res. 36 ve Şek. 34'den düzenlenmiştir), Vakıfiğdemir Kalkan Göbeği (3) (Yazar)

Resim 5: Kozman Deresi (1-3) (Harmankaya, 1995: Lev. 2a, b, 3a), Tekhöyük Tümülüsü (4) (Erdoğdu, 1999: şek. 32'den düzenlenmiştir), Vize A Tümülüsü (5) (Aksan, 2015: Res. 384), Vakıfiğgdemir (6) (Yazar) Buluntusu Kılıçlar

Resim 6: Kozman Deresi (1-3) (Harmankaya, 1995: Lev. 3b, 4a, b), Bakacaktepe (4) (Yazar), Yündolan C Tümülüsü (5-10) (Delemen vd. 2010a: Fig. 13 ve 14'den düzenlenmiştir) (ölçeksiz), Karağaçtepe Tümülüsü (11) (Yazar), Naip Tümülüsü (12-15) (Delemen, 2004: fig. 110'dan düzenlenmiştir), Tekhöyük Tümülüsü (16-17) (Erdoğdu, 1999: şek. 32'den düzenlenmiştir), Demirköy Tümülüsü (18-19) (Edirne Müzesi Arşivi), İkiztepe B Tümülüsü (20-21) (Şahin Yıldırım Arşivi), Vize A Tümülüsü (2223) (Aksan, 2015: Res. 385, 386), Vize E Tümülüsü (24-26) (Aksan, 2015: Res. 476, 477, 478), Vezirtepe Tümülüsü (27-29) (Yazar), Vakfidemir (30-31) (Yazar) ve Dolucatepe (32) (Yazar) Mızrak Uçları

Resim 7: Ok Uçları (Bakacaktepe (1-16) (Yazar), Heraion Teikhos (17-24) (Atik 2017: Resim 2, 4 ve 6'dan düzenlenmiştir), Hıdırağa (25) (Didem Baş Arşivi), Pınarhisar (26) (Didem Baş Arşivi), Keşan (27) (Didem Baş Arşivi), Tekirdağ (28) (Didem Baş Arşivi), Çokal (29) (Yazar) Ok Uçları 
DOĞU TRAKYA BULUNTUSU

SAVUNMA VE SALDIRI GEREÇLERİ

Resim 8: Heraion Teikhos (1) (Ölçeksiz) (Atik, 2016: Res. 8'den düzenlenmiştir), Büyük Anafarta Köyü (Alopekonnesos) (2-5) (Yazar), Pınarhisar (6-8) (Didem Baş Arşivi) Kurşun Sapan Taneleri

Tablo 1: Doğu Trakya Savunma ve Saldırı Gereçlerinin Buluntu Yerlerine Göre Sayısal Dağılımı

Tablo 2: Doğu Trakya Savunma Gereçlerinin Tarihsel Dağılımları

Tablo 3: Doğu Trakya Saldırı Gereçlerinin Tarihsel Dağılımları

Tablo 4: Doğu Trakya Buluntularının Tarihsel Dağılımı

\section{KAYNAKÇA}

\section{Antik Kaynaklar}

Demosthenes, Demosthenes, Çev. J. H. VINCE, M.A. Cambridge, Harvard University Press, William Heinemann Ltd., London, 1930.

Herodotos, Herodot Tarihi, Çev. M. ÖKMEN, Remzi Kitapevi Yayınları, İstanbul, 1991.

\section{Modern Kaynaklar}

AKÇAY, Tuna (Nisan-Mayıs 2018), “Olba'daki Ok Uçları Işı̆̆ında Kentteki Askeri Hareketlilik Hakkında Düşünceler”, Seleucia, 8, 91-122.

AKSAN, Zeki Mete (2015), Güneydoğu Thrakia Tümülüsleri: 1881-1964 Yıllarında Kazılan Tümülüslerin Yeniden Değerlendirilmesi, Doktora Tezi, İstanbul Üniversitesi, İstanbul.

ALAGÖZ, Umut (2012), Zeugma Antik Kenti Dionysos ve A Evleri Metal Buluntulart, Yüksek Lisans Tezi, Ankara Üniversitesi, Ankara.

ATİK, Neşe (2017) "Heraion Teikhos Kazılarında Bulunan Ok Uçları”, Masrop EDergi, 11.16, 57-76.

ATİK, Neşe (Mayıs-Ağustos 2016), “Tekirdağ’da Traklar ve Antik Heraion Teikhos Kenti”, Arkeoloji ve Sanat Dergisi, 152, 75-86.

BAŞ, Didem (2019), Edirne Arkeoloji Müzesi Metal Buluntulart, Yüksek Lisans Tezi, Trakya Üniversitesi, Edirne.

BAŞ, Didem (2021), "Edirne Arkeoloji Müzesi'nden Bir Grup Metal Buluntu”, MASROP E-Dergi, 15.1, 5-40.

BATUR, Gizem (2021), Hadrianopolis (Edirne) ile Yakın Çevresi Tümülüsleri ve Buluntularl, Yüksek Lisans Tezi, Trakya Üniversitesi, Edirne. 
BAYKAN, Daniş (2017), "Nif Dağı Kazısı Karamattepe ve Ballıcaoluk'ta Bulunan Ok Uçları", MASROP E-Dergi, 9.12-13 (2015), 18-40.

ÇOKAMAN, Elif ve KIRÇIN, Şahan (2015), "Edirne Müzesi Lalapaşa Demirköy Tümülüsü Kurtarma Kazısı", 23. Müze Çalışmaları ve Kurtarma Kazıları Sетровуити, Ankara, 69-82.

ÇOKAMAN, Elif ve KIRÇIN, Şahan (Ağustos 2016), "Edirne Lalapaşa Demirköy Tümülüsü Kazısı", Arkeoloji ve Sanat Dergisi, 152, 147-152.

DAVIDSON, Gladys R. (1952), Corinth Vol. XII, The Minor Objects, American School of Classical Studies at Athens, Princeton.

DELEMEN, İnci (2004), Tekirdağ Naip Tümülüsü, Ege Yayınları, İstanbul.

DELEMEN, İnci, ÇOKAY KEPÇE, Sedef, YILMAZ, Zülküf (2010a), “A "Warrior" Burial of The Mid-Fourth Century BC in Southeastern Thrace: Tumulus C at Yündolan Near Kırklareli”, TÜBA-AR, 13, 91-106.

DELEMEN, İnci, ÇOKAY KEPÇE, Sedef, YILMAZ, Zülküf (2010b), "Kırklareli Yündolan C Tümülüsü”, Colloquium Anatolicum, 9, 1-18.

DEMİRER, Ünal (2013), Kibyra Metal Buluntularl, Doktora Tezi, Akdeniz Üniversitesi, Antalya.

DEONNA, Waldemar (1938), Exploration Archéologique de Délos, le Mobilier Délien Boccard Yayınları, Paris.

ERDOĞDU, Ayșe (1999), Hayrabolu Hacıllı Tek Höyük Tümülüsü Buluntuları, Yüksek Lisans Tezi, Ankara Üniversitesi, Ankara.

EROL, Ayşe F. ve YILDIRIM, Ertaç (Eylül-Aralık 2016), "Fatsa Cingırt Kayası Kazısında Bulunan Ok Uçları", Arkeoloji ve Sanat Dergisi, 153, 133-148.

FILOV, Bogdan (2013), Balkan Savaşları Günlüğ̈̈, Yay. Haz. Hüseyin MEVSiM, Timaş Yayınları, İstanbul.

HARMANKAYA, Savaş (1995), "Kozman Deresi Mevkii (Şarköy, Tekirdağ) Maden Buluntuları", Halet Çambel İçin Prehistorya Yazıları, Graphis Yayınları, İstanbul, 217-254.

HASLUCK, Frederick William (1910/1911), "A Tholos Tomb at Kirk Kilisse”, The Annual of the British School at Athens, 17, 76-79.

HRISTODOULOS, Melisinos (1897), İ Thraki ke E Saranta Ekklisie Meta Tinon Diikitikon Ekklisiastikon Zitimaton (Yunanca), İstanbul.

JAMES, Simon, (2004), The excavations at Dura Europos conducted by Yale University and the French Academy of inscriptions and letters 1928 to 1937, Final report 7, Arms and armour and other military equipment, Oxbow Books, Oxford. 
DOĞU TRAKYA BULUNTUSU

SAVUNMA VE SALDIRI GEREÇLERİ

JOUBIN, André (1898), Musée impérial Ottoman. Bronzes et bijoux. Catalogue sommaire, İstanbul.

KAKAVAS, George (ed) (2013), Leaving a Mark on History, Treasures From Grek Museums, Atina.

KARACA, Ergün (2019), Milattan Önce Birinci Binde Doğu Trakya, Homer Kitapevi, İstanbul.

KOÇEL ERDEM, Zeynep (2009), "Preliminary Report of the Tekirdağ Ganos 2008 Survey", Anatolia Antiqua, 17, 411-426.

KOÇEL ERDEM, Zeynep (2010), “Tekirdağ Ganos 2009 Survey”, Anatolia Antiqua, 18, 305-320. doi: https://doi.org/10.3406/anata.2010.1317

KOÇEL ERDEM, Zeynep (2011), “Tekirdağ Ganos Dağı 2009 Yüzey Araştırması”, 28. Araştırma Sonuçları Toplantısı, 2. Cilt, Ankara, 385-408.

MANSEL, Arif Müfit (Nisan 1944), “Vize’de Bulunan Maskeli Miğfer”, Belleten, 8.30, 165-183.

MANSEL, Arif Müfit (Ocak 1940), “Trakya Hafriyatı”, Belleten, 4.13, 89-114.

MANSEL, Arif Müfit (Temmuz 1939), “1939 Senesi Trakya Hafriyatı”, Belleten, 3.11-12, 460-462.

ONURKAN, Somay (1978), "Vize-A Tümülüsünden Bir Zırh Gömlek”, Güneydoğu Avrupa Araştırmaları Dergisi, 6/7, 47-55.

ONURKAN, Somay (1988), Doğu Trakya Tümülüsleri Maden Eserleri, İstanbul Arkeoloji Müzelerindeki Trakya Toplu Buluntuları, TTK Yayınları, Ankara.

ORANSAY, B. S. Alptekin, (2006), Arykanda Antik Kentinde 1971- 2002 Kazl Sezonlarında Ele Geçen Madeni Buluntular ve Madencilik Faaliyetleri, Doktora Tezi, Ankara Üniversitesi, Ankara.

ÖZTÜRK, N. Önder (1998), “Hayrabolu Hacıllı Köyü Tekhöyük Tümülüsü Kurtarma Kazısı", 8. Müze Kurtarma Kazllarl Semineri, Ankara, 381391.

POLAT, Mehmet Ali (Ağustos 2016), “Cambaztepe Tümülüsü (Kurgan) Kazısı Ön Değerlendirmesi”, Arkeoloji ve Sanat Dergisi, 152, 231-236.

ROBINSON, Devid M. (1941), Excavations at Olynthus. X. Metal and Minor Miscelleaneous Finds, Johns Hopkins Press, London.

SAYAR, Mustafa Hamdi (1993), "Doğu Trakya'da Epigrafi ve Tarihi-Coğrafya Araştırmaları”, 10. Araştırma Sonuçları Toplantısı, Ankara, 153-173. 
SIMKIN, Michael (2001), The Roman Army from Hadrian to Constantine, Osprey Publishing Ltd., Oxford.

TEKIN, Halil (2018), Maden Eser Tipolojisi, Bilgin Kültür Sanat Yayınları, Ankara.

YILDIRIM, Şahin (2002), Trakya Tümülüsleri ve Lokalizasyonu, Yüksek Lisans Tezi, Ankara Üniversitesi, Ankara.

YILDIRIM, Şahin (2007), “Trakya'da Tümülüs Tipi Mezar Geleneği ve İkiztepe B Tümülüsü”, Aktüel Arkeoloji, 3, 83-90.

YILDIRIM, Şahin (2012), Doğu Trakya'da Mezar Tepelerinin Ortaya Çıkışı ve Gelişimi, Ankara Üniversitesi Yayınları, Ankara.

YILMAZ, Zülküf (2001), "Kırklareli Müzesi Yündolan C Tümülüsü Kurtarma Kazısı", 11. Müze Çalışmaları ve Kurtarma Kazıları Sempozyumu, Ankara, 71-82. 
DOĞU TRAKYA BULUNTUSU

SAVUNMA VE SALDIRI GEREÇLERİ

\section{EKLER}

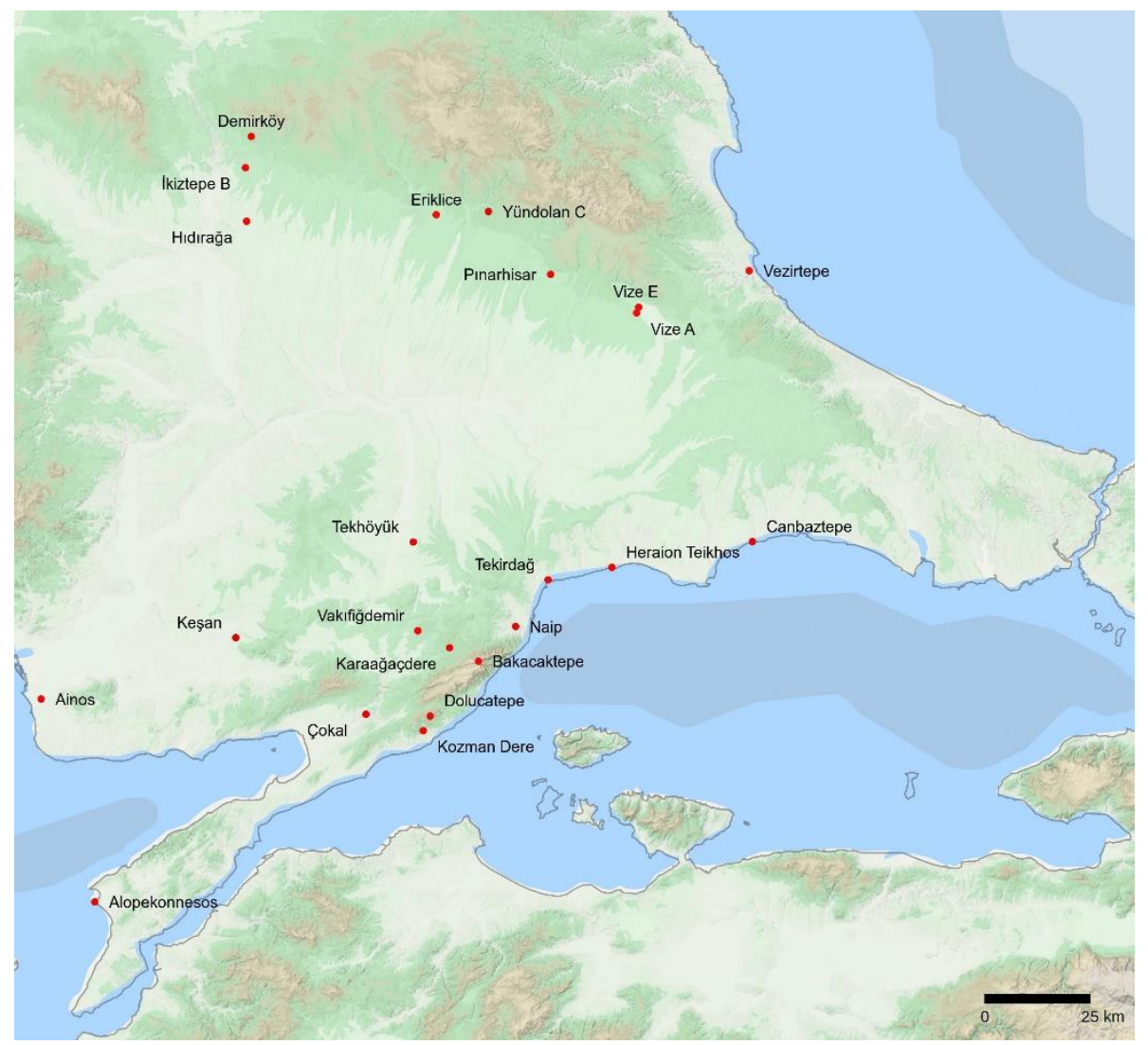

Resim 1: Doğu Trakya Buluntusu Savunma ve Saldırı Gereçlerinin Ele Geçtiği Merkezler 

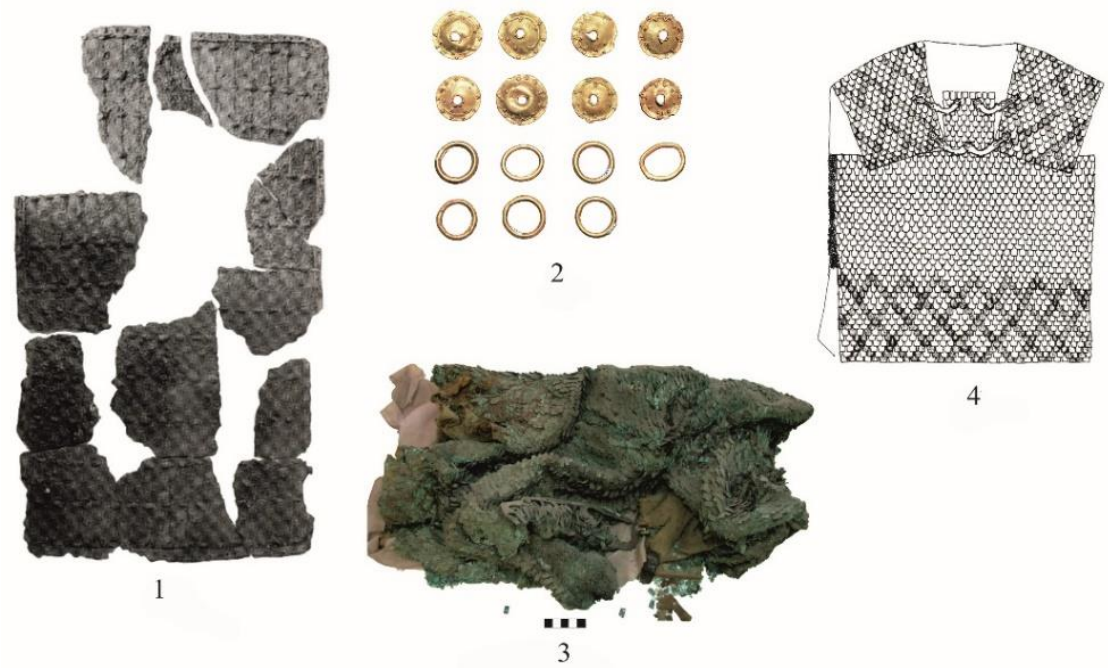

Resim 2: Yündolan C Tümülüsü Zırh Plakaları (1), Naip Tümülüsü Zırha Ait Levha ve Halkalar (2), Vize A Tümülüsü Zırh ve Çizimi (3-4)
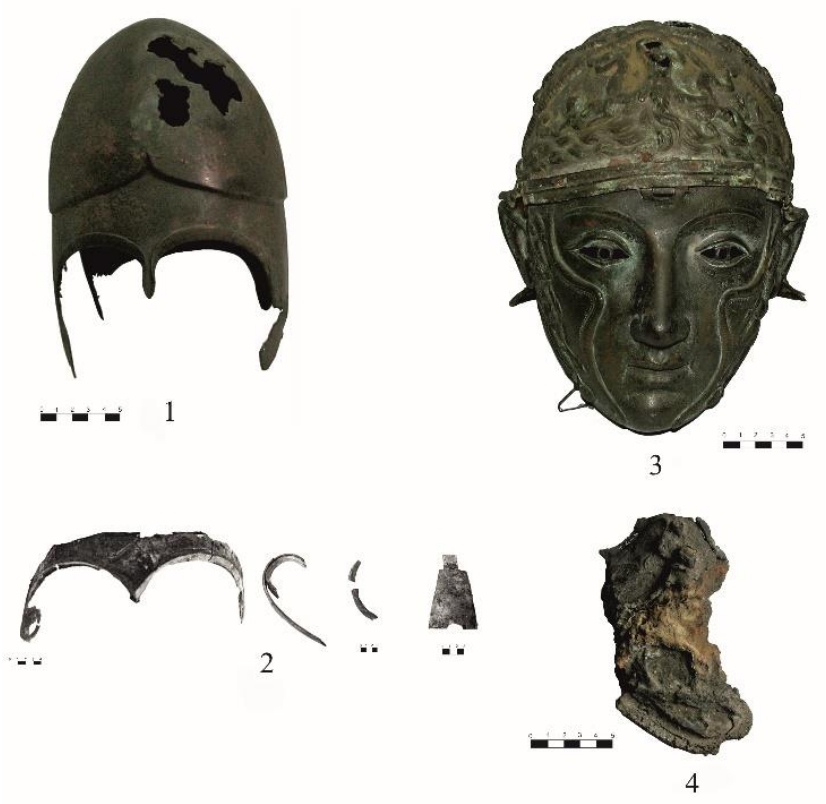

Resim 3: Eriklice Tümülüsü Miğfer (1), Naip Tümülüsü Miğfer Parçaları (2), Vize A Tümülüsü Miğfer (3), Vize E Tümülüsü Miğfer Parçası (4) 

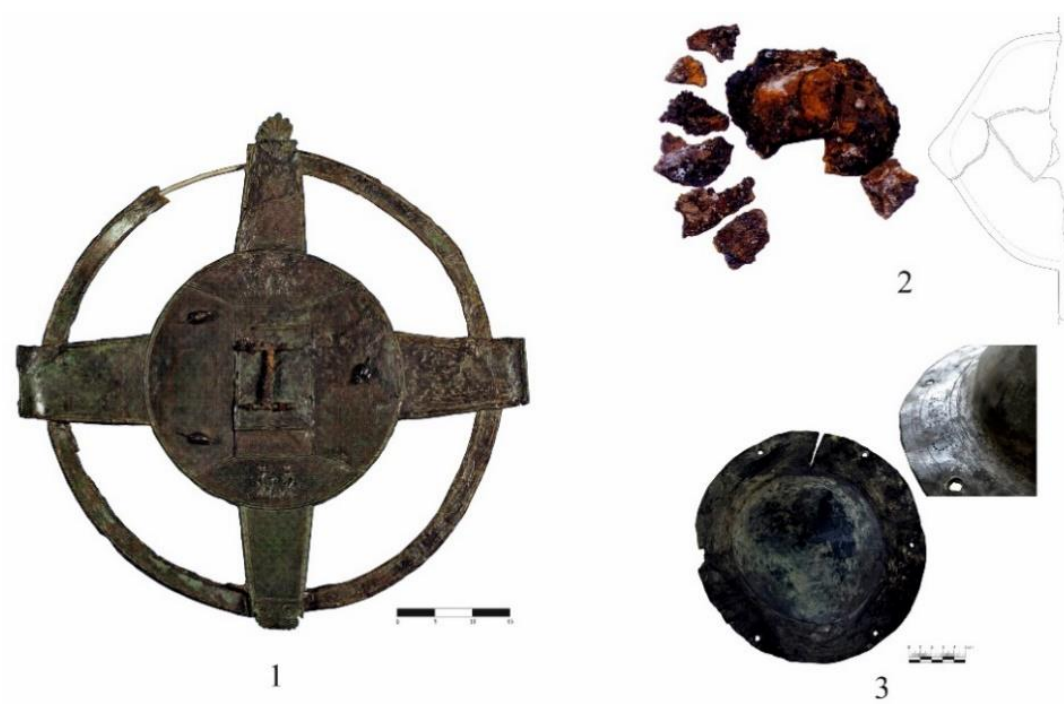

Resim 4: Naip Tümülüsü Kalkan Parçası (1), Tekhöyük Tümülüsü Kalkan Göbeği Parçaları ve Çizimi (2) (Ölçeksiz), Vakıfiğdemir Kalkan Göbeği (3)

1

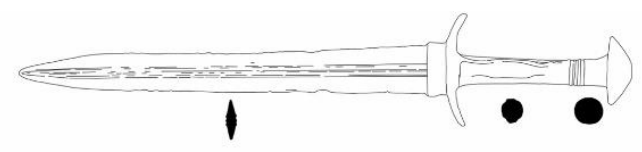

2

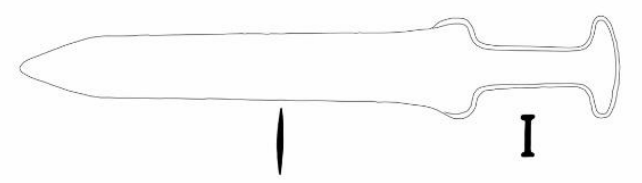

3

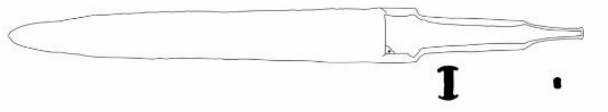

4

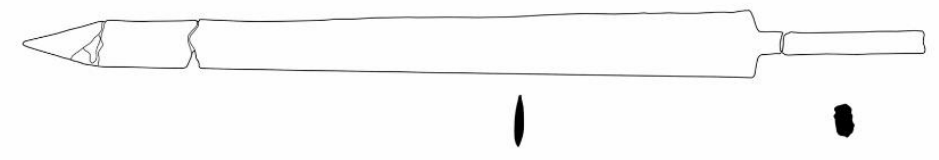

5

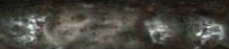

6

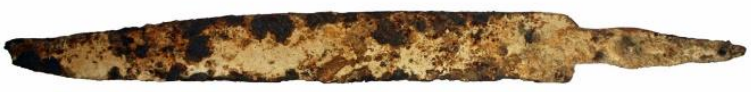

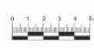

Resim 5: Kozman Deresi (1-3), Tekhöyük Tümülüsü (4), Vize A Tümülüsü (5), Vakıfiğdemir (6) Kılıçlar

Trakya Üniversitesi Edebiyat Fakültesi Dergisi, 


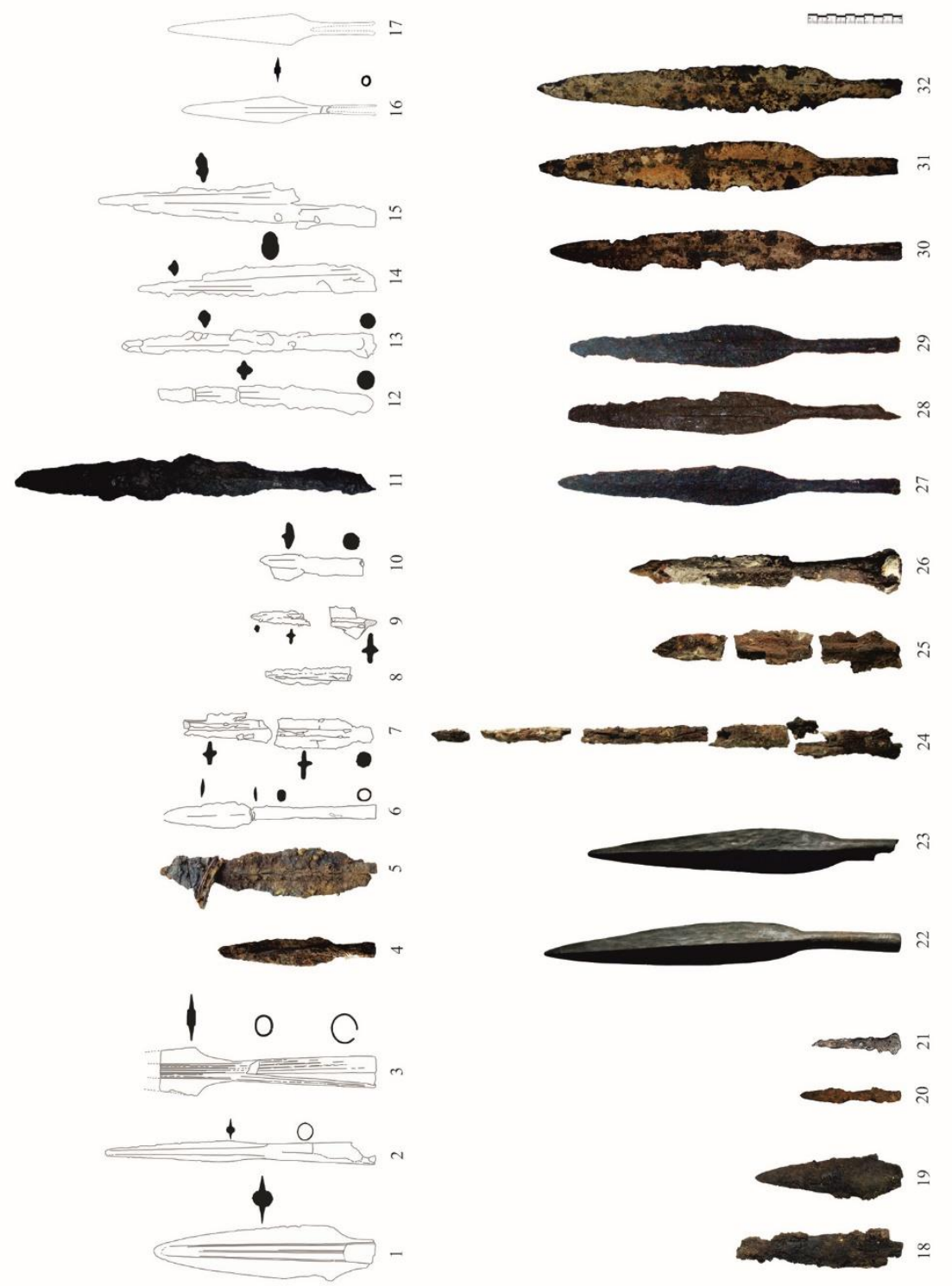

Resim 6: Kozman Deresi (1-3), Bakacaktepe (4), Yündolan C Tümülüsü (5-10), Karağaçtepe Tümülüsü (11), Naip Tümülüsü (12-15), Tekhöyük Tümülüsü (16-17), Demirköy Tümülüsü (18-19), İkiztepe B Tümülüsü (20-21), Vize A Tümülüsü (2223), Vize E Tümülüsü (24-26), Vezirtepe Tümülüsü (27-29), Dolucatepe (30) ve Vakfidemir (31-32) Mızrak Uçları 

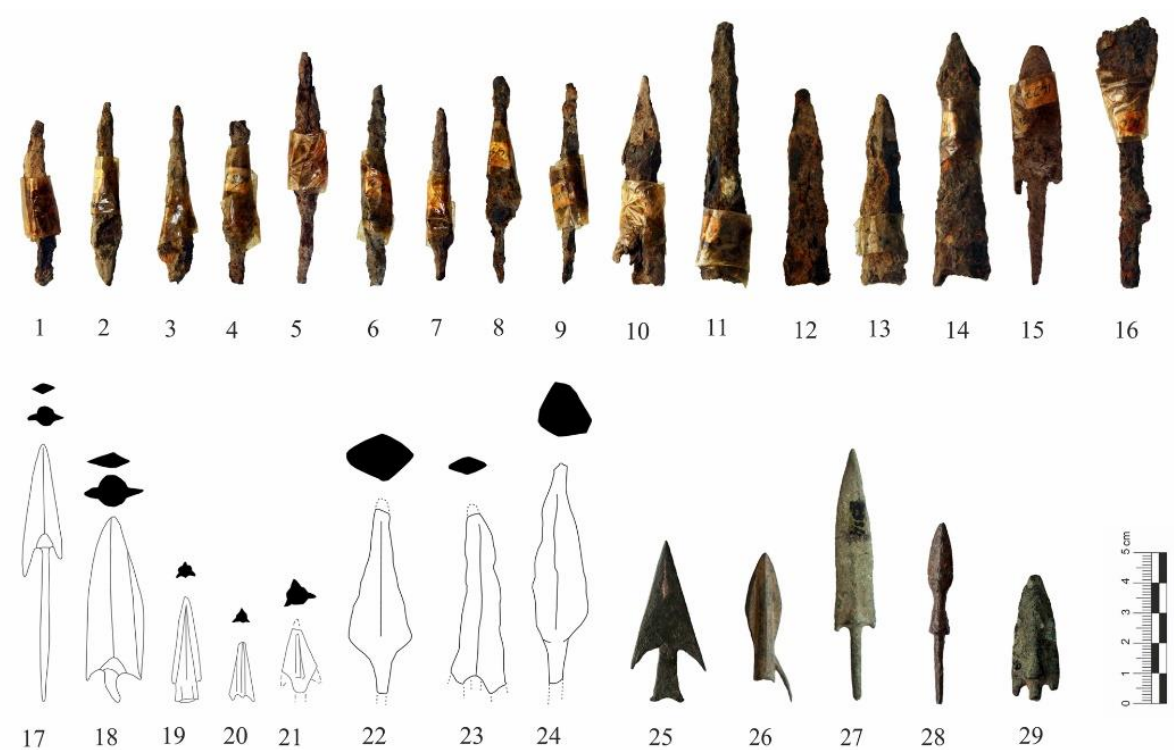

Resim 7: Bakacaktepe (1-16), Heraion Teikhos (17-24), Hıdırağa (25), Pınarhisar (26), Keşan (27), Tekirdağ (28), Çokal (29) Ok Uçları

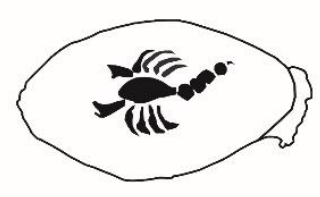

1

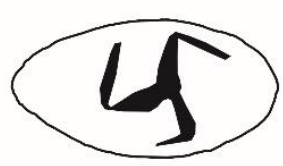

2

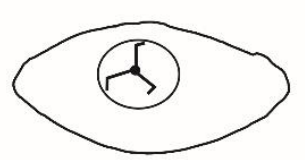

3
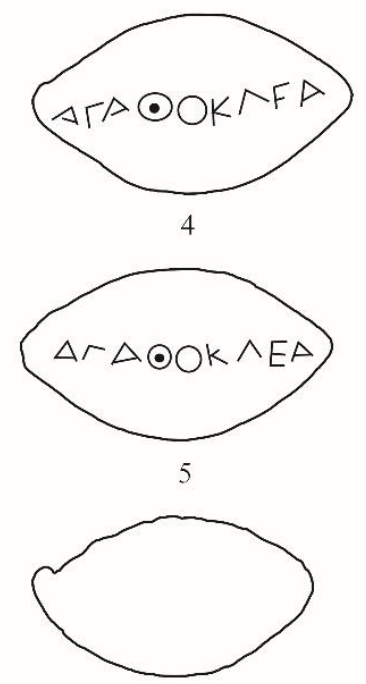

6
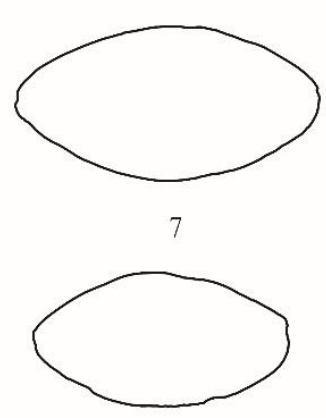

8

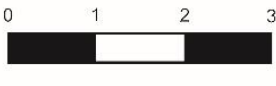

Resim 8: Heraion Teikhos (1) (Ölçeksiz), Büyük Anafarta Köyü (Alopekonnesos) (2-5), Pınarhisar (6-8) Kurşun Sapan Taneleri 


\begin{tabular}{|l|c|c|c|c|c|c|c|}
\hline \multicolumn{1}{|c|}{ Buluntu Yeri } & Zırh & Miğfer & Kalkan & Kılıç & $\begin{array}{c}\text { Mızrak } \\
\text { Ucu }\end{array}$ & $\begin{array}{c}\text { Ok } \\
\text { Ucu }\end{array}$ & $\begin{array}{c}\text { Sapan } \\
\text { Tanesi }\end{array}$ \\
\hline Ainos & - & - & - & - & - & 1 & \\
\hline Bakacaktepe & - & - & - & - & 1 & 16 & - \\
\hline Cambaztepe & - & - & - & - & - & 1 & - \\
\hline Demirköy & - & - & - & - & 2 & - & - \\
\hline Dolucatepe & - & - & - & - & 1 & - & - \\
\hline Eriklice & - & 1 & - & - & - & - & - \\
\hline Heraion Teikhos & - & - & - & - & - & 29 & $\begin{array}{c}\text { Birden } \\
\text { fazla }\end{array}$ \\
\hline İkiztepe & - & - & - & - & 2 & - & - \\
\hline Karaağaç & - & - & - & - & 1 & - & - \\
\hline Kozman Deresi & - & - & - & 3 & 3 & - & - \\
\hline Naip & 1 & 2 & 1 & - & 2 & - & - \\
\hline Tekhöyük & - & - & 1 & 1 & 2 & - & - \\
\hline Vezirtepe & & & & & 3 & & \\
\hline Vize A & 1 & 1 & & 1 & 2 & & \\
\hline Vize E & & 1 & & & 3 & & \\
\hline Yündolan C & 1 & - & - & - & 8 & - & - \\
\hline Vakıfiğdemir & - & - & 1 & 1 & 2 & - & - \\
\hline Hıdırağa & - & - & - & - & - & 1 & - \\
\hline Pınarhisar & - & - & - & - & - & 1 & - \\
\hline Keşan & - & - & - & - & - & 1 & - \\
\hline Tekirdağ & - & - & - & - & - & 1 & - \\
\hline Çokal & - & - & - & - & - & 1 & - \\
\hline Alopekonnesos & - & - & - & - & - & - & 4 \\
\hline Pınarhisar & - & - & - & - & - & - & 3 \\
\hline
\end{tabular}

Tablo 1: Doğu Trakya Savunma ve Saldırı Gereçlerinin Buluntu Yerlerine Göre Sayısal Dağılımı
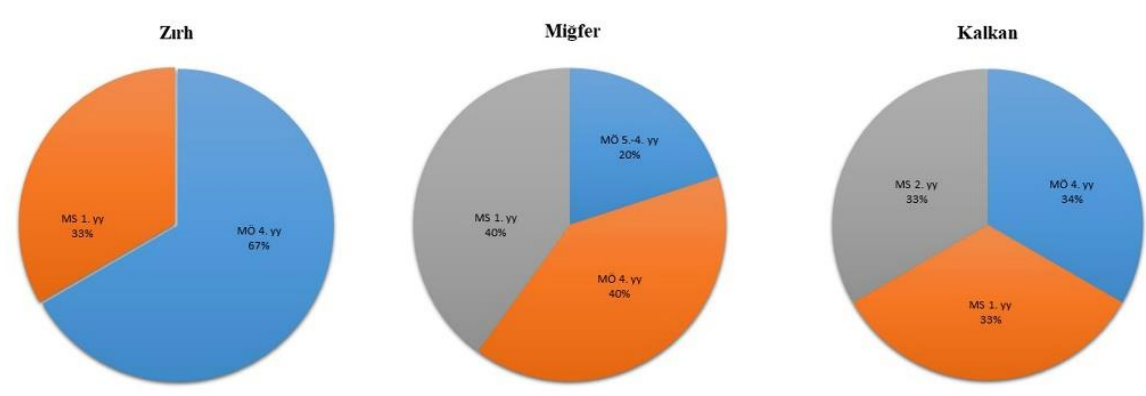

Tablo 2: Doğu Trakya Savunma Gereçlerinin Tarihsel Dağılımları 
DOĞU TRAKYA BULUNTUSU

SAVUNMA VE SALDIRI GEREÇLERİ

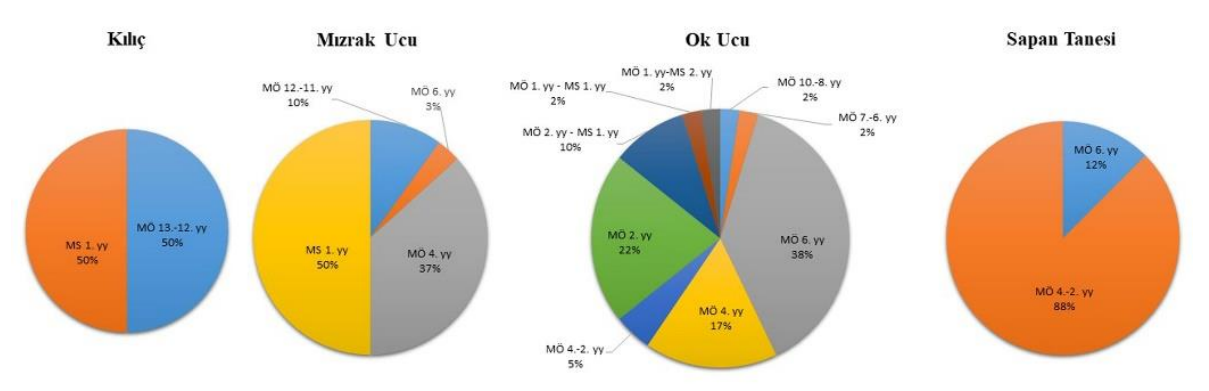

Tablo 3: Doğu Trakya Saldırı Gereçlerinin Tarihsel Dağılımları

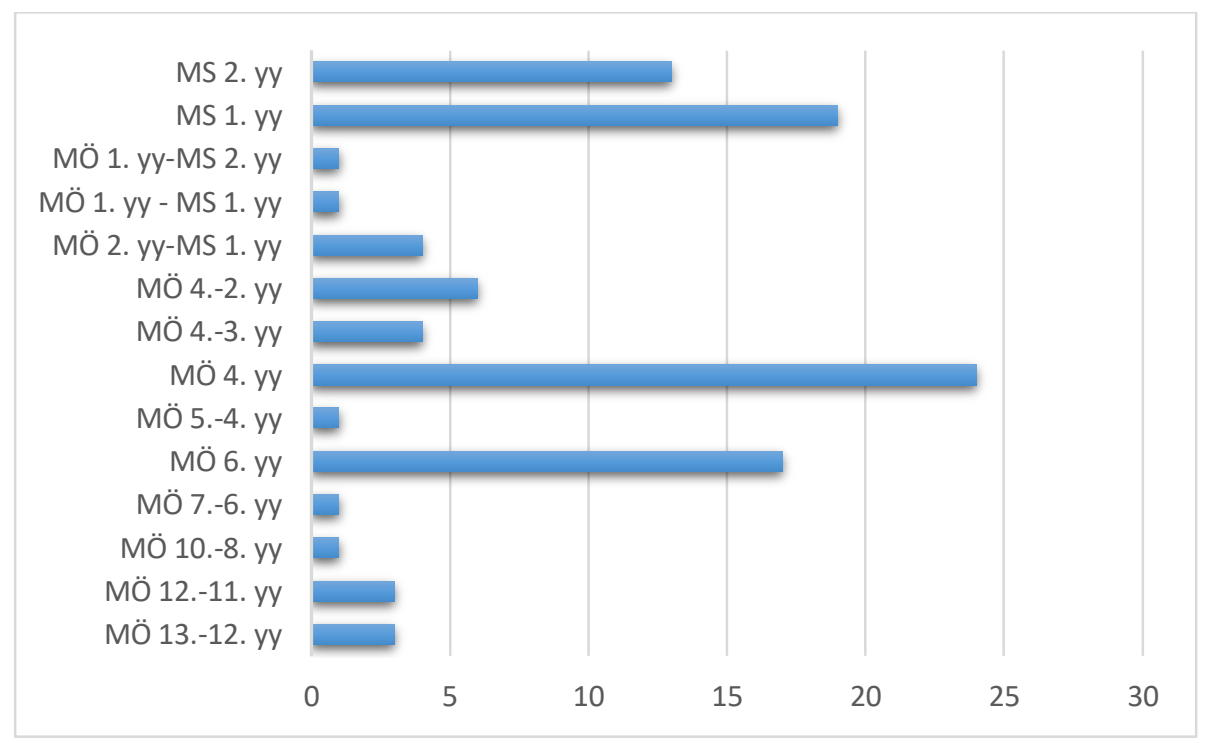

Tablo 4: Doğu Trakya Buluntularının Tarihsel Dağılımı 